\title{
COMMENT
}

\section{THEFT LOSS DEDUCTIONS AS RELIEF FOR THE SMALL INVESTOR}

With the development of federal corporation law and the implementation of that law by the Securities and Exchange Commission (SEC), shareholders are becoming increasingly aware of the rights and remedies available to them whenever they find themselves injured as a proximate result of a securities fraud. ${ }^{1}$ In addition to securities law remedies, tax law affords some relief for losses due to securities fraud, but only under relatively limited circumstances. As will be discussed, none of the presently available remedies are particularly effective for the small investor. This Comment will propose an alternative which would provide greater tax relief for the small investor than has been heretofore available. That alternative is the theft loss deduction. ${ }^{2}$

\section{The Plight of the Small Investor Who is a Victim of a Securities Fraud}

The investor who has been the victim of a securities fraud is likely to discover that the fraudulent activity caused his security to decline significantly in value. There are two basic ways in which the fraudulent activity can cause a loss in value. First, the fraud could have been perpetrated in order to conceal the fact that the corporate entity backing the security is worth less than previously believed. Second, evidence that a security has been tainted by fraud causes the SEC to take action which usually affects the market adversely. Suspension of trading ${ }^{3}$ and

\footnotetext{
THE FOLLOWING CITATIONS WILL BE USED IN THIS COMMENT:

A. BROMBerg, SeCurities LAW (1967-1977) [hereinafter cited as A. BrombERG];

W. LaFave \& A. ScotT, Criminal LaW (1972) [hereinafter cited as W. LaFave \& A. ScotT].

1. "In its quasi-judicial jurisdiction over violations of the securities laws by broker-dealers and in its powers to investigate and publish violations by anyone, [the SEC] has developed many of the important precedents in the area [of securities fraud] . . . Activities of this kind have called investor attention to specific violations and general rights, thereby encouraging injured parties to sue." 4 A. Bromberg $\& 10.1$, at 234.

2. Defrauded investors are beginning to turn to the theft loss deduction as other opportunitites for relief become unavailable. For example, investors in Home-Stake Production Co. lost approximately $\$ 120,000,000$ as a result of a securities fraud. D. MCClintick, STEALING From THE RICH 301-03 (1977). Because other avenues of relief do not provide adequate compensation for their loss, investors in the Home-Stake oil swindle are currently attempting to claim some relief for their loss under the theft loss provision of the Internal Revenue Code. Id. 298 n.4.

3. Section 12(k) of the Securities Exchange Act of 1934 provides:

If in its opinion the public interest and the protection of investors so require, the
} 
other types of SEC enforcement action-injunctions, administrative proceedings and criminal proceedings-are events by which the market is formally apprised that certain issuers are allegedly in violation of the federal securities laws. ${ }^{4}$ SEC releases generally indicate the nature of the violation. ${ }^{5}$ Although market surveillance, the dissemination of information obtained pursuant to surveillance and the resultant enforcement action are intended to protect investors, one inevitable result of SEC enforcement action is a negative market reaction in the security's price. ${ }^{6}$ The suspension order may apply for several years, ${ }^{7}$ thereby sub-

Commission is authorized summarily to suspend trading in any security (other than an exempted security) for a period not exceeding ten days . . . .

15 U.S.C. $\$ 78 l(\mathrm{k})$ (1976). See also 2 A. BROMBERG $§ 7.1$, at 143.

4. 15 U.S.C. $\$ 78 u(d)$ (1976) (injunction proceedings); id. $\S 78 \mathrm{o}(\mathrm{b})(4)$ (administrative proceedings); id. § $78 f$ (criminal proceedings). See also 17 C.F.R. \& 202.5(b) (1977):

Where it appears after investigation or otherwise that there has been a violation of any of the provisions of the acts administered by the Commission or the rules or regulations thereunder, the Commission may take one or more of the following actions: institution of administrative proceedings looking to the imposition of remedial sanctions, initiation of injunction proceedings in the courts, and, in the case of a willful violation, reference of the matter to the Department of Justice for criminal prosecution.

5. [1977] 1 FED. SEC. L. REP. (CCH) I 323(11). The statutory basis of the SEC's authority is section 21 of the Securities Exchange Act of 1934:

The Commission is authorized, in its discretion, to publish information concerning any such violations, and to investigate any facts, conditions, practices, or matters which it may deem necessary or proper to aid in the enforcement of such provisions, in the prescribing of rules and regulations under this title, or in securing information to serve as a basis for recommending further legislation concerning the matters to which this title relates.

15 U.S.C. \& 78u (1976). See also Kukatush Mining Corp. v. SEC, 198 F. Supp. 508 (D.D.C. 1961).

6. 2 A. BROMBERG $\$ 7.1$, at 143 n.11.

7. See Sloan v. SEC, 98 S. Ct. 1702 (1978), aff'g 547 F.2d 152 (2d Cir. 1976) (SEC has no power to summarily roll-over the ten-day suspension period pursuant to 15 U.S.C. $\& 78 /(\mathrm{k})$ (1976)). See also Brief for Petitioner, Ecological Science Corp. v. SEC, [1972-1973 Transfer Binder] FED. SEC. L. REP.(CCH) \ 93,663 (D.C. Cir. 1972) (allegation that suspension of stock from trading for fifty-one ten-day periods constitutes a grave abuse of discretion).

In both Sloan and Ecological Science Corp. the SEC had exercised its power to suspend trading pursuant to section 12(k) of the Securities Exchange Act of 1934. See note 3 supra. However, in 1975 Congress expanded $\S 12(j)$ to include a power to suspend trading. Consequently, that section allows the Commission

to suspend for a period not exceeding twelve months, or to revoke the registration of a security, if the Commission finds on the record after notice and opportunity for hearing, that the issuer of such security has failed to comply with any provision of this chapter or the rules and regulations thereunder.

15 U.S.C. $\$ 78 /(j)$ (1976). Apparently, Congress now intends for the SEC to use section 12(j) for suspensions of extended duration. See S. REP. No. 75, 94th Cong., Ist Sess. 105-06 (1975) ("With this change, the Commission is expected to use this section rather than its ten-day suspension power, in cases of extended duration.").

Regarding the SEC's use of its power to suspend trading, the concurring opinion of Mr. Justice Brennan and Mr. Justice Marshall in the Sloan case noted that "the Commission has used $\S 12(\mathrm{k})$, or its predecessor statutes to suspend trading in a security for up to 13 years . . . . And, although the 13-year suspension is an extreme example, the record is replete with suspensions lasting the better part of a year." Sloan, $98 \mathrm{~S}$. Ct. at 1714-15. See also S. REP. No. 379, 88th Cong., Ist Sess. 66-67 (1963) ("The [Senate Committee on Banking and Currency] recognizes that 
stantially reducing the value of the stock and eliminating the market in which the shareholder could sell his shares in order to realize whatever value remained in his asset.

Shareholders may bring a direct action ${ }^{8}$ for damages under certain antifraud provisions of the federal securities laws, for example, section 10(b) of the Securities Exchange Act of $1934^{9}$ and Rule 10b-5. ${ }^{10}$ However, a shareholder frequently is unable to pursue such relief, either because he is unable to meet the standing requirements of Rule $10 \mathrm{~b}-5^{11}$ or because the corporate defendant may not possess sufficient assets with which to compensate the shareholder. ${ }^{12}$ Further, where the individual loss is relatively small, private actions to recover damages are

suspension of trading in a security is a drastic step and that prolonged suspension of trading may impose considerable hardship on stockholders.").

8. It is important to note the distinction between a direct personal or representative suit and a derivative suit. In a derivative suit the alleged wrong was not done to the plaintiff personally, but to the corporation. In a direct personal suit, "the corporation is charged with invasion of the stockholder's independent right." W. CARY, CORPORATIONS, CASES AND MATERIALS 733 (4th ed. abridged 1970) (quoting Justice Frankfurter's dissent in Smith v. Sperling, 354 U.S. 91,99 (1957)). "A representative action is a class action or a direct personal action brought on behalf of those 'similarly situated." " W. CARY, supra, at 729 n.2 (quoting Reifsnyder v. Pittsburgh Outdoor Advertising Co., $405 \mathrm{~Pa} .142,144$ n.2, 173 A.2d 319, 320 n.2 (1961)). Theft loss deductions should be available to investors only when corporate officers have violated an antifraud provision of the securities laws to which the investor has a direct personal or representative action since a theft loss deduction would be compensating the shareholder for a personal loss.

9. 15 U.S.C. $§ 78 \mathrm{j}(\mathrm{b})$ (1976). The section provides:

It shall be unlawful for any person, directly or indirectly, by the use of any means or instrumentality of interstate commerce or of the mails, or of any facility of any national securities exchange-

(b) To use or employ, in connection with the purchase or sale of any security registered on a national securities exchange or any security not so registered, any manipulative or deceptive device or contrivance in contravention of such rules and regulations as the Commission may prescribe as necessary or appropriate in the public interest or for the protection of investors.

10. 17 C.F.R. $\$ 240.10 \mathrm{~b}-5$ (1977). The rule provides:

It shall be unlawful for any person, directly or indirectly, by the use of any means or instrumentality of interstate commerce, or of the mails or of any facility of any national securities exchange,

(a) To employ any device, scheme, or artifice to defraud,

(b) To make any untrue statement of a material fact or to omit to state a material fact necessary in order to make the statements made, in the light of the circumstances under which they were made, not misleading, or

(c) To engage in any act, practice, or course of business which operates or would operate as a fraud or deceit upon any person,

in connection with the purchase or sale of any security.

11. See, e.g., Blue Chip Stamps v. Manor Drug Stores, 421 U.S. 723 (1975); Birnbaum v. Newport Steel Corp., 193 F.2d 461 (2d Cir.), cert. denied, 343 U.S. 956 (1952) (purchase-seller requirement). See text accompanying notes $94-96$ infra.

12. For example, a corporation in bankruptcy must distribute assets to creditors in accordance with the provisions of bankruptcy law. However, it is unlikely that there will be any assets to distribute to shareholders since creditors of the corporation must be compensated first. H. HENN, LAW OF CORPORATIONS \& 383, at 822-23 (2d ed. 1970). 
generally brought in the form of class actions. ${ }^{13}$ In Eisen v. Carlisle \& Jacquelin, ${ }^{14}$ the Supreme Court held that representatives of a commonquestion class action must bear the cost of giving individual notice to all members of a class who can be identified and located. ${ }^{15}$ This considerable expense may preclude small investors, as a practical matter, from seeking relief. ${ }^{16}$ Consequently, the only relief that may be available is a tax deduction for the loss. ${ }^{17}$

Section 165(c)(2) of the Internal Revenue Code allows an individual a deduction for losses incurred in any transaction entered into for profit, though not connected with a trade or business, and losses of all non-business property resulting from fire, storm, shipwreck or other casualty or from theft are deductible under section 165 (c)(3).$^{18}$ Section 165(f) allows a capital loss arising from the sale or exchange of securities $^{19}$ and section $165(\mathrm{~g})$ allows a deduction for securities which have become worthless during the taxable year. ${ }^{20}$

All of the above provisions, with the exception of section 165(c)(3),

13. Eisen v. Carlisle \& Jacquelin, 391 F.2d 555, 560 (2d Cir. 1968) vacated and remanded on other grounds 417 U.S. 156 (1974).

14. 417 U.S. 156 (1974).

15. Id. at $173-77$.

16. Id. at 178-79.

17. "If the class suit is to enable a single plaintiff with a small individual claim to represent an entire class of victims with an enormous total claim, Eisen has destroyed its utility unless that single plaintiff is very wealthy." Lyons, Class Actions, 1974/75 ANN. Survey AM. L. 349, 356. "Unfortunately, even notice by publication could be prohibitively expensive if the class is very large." Id. 360. But see Patrick, The Securities Class Action for Damages Comes of Age (19661974), 29 Bus. LAw. 159 (Special Issue 1974). The requirement of individual notice "will probably not have much impact on class actions under the federal securities acts." Id. 164.

18. I.R.C. $\& 165$ provides:

(a) General Rule-There shall be allowed any loss sustained during the taxable year and not compensated for by insurance or otherwise.

(c) Limitation on Losses of Individuals - In the case of an individual, the deduction under subsection (a) shall be limited to-

(1) losses incurred in a trade or business;

(2) losses incurred in any transaction entered into for profit, though not connected with a trade or business; and

(3) losses of property not connected with a trade or business, if such losses arise from fire, storm, shipwreck, or other casualty, or from theft. A loss described in this paragraph shall be allowed only to the extent that the amount of loss to such individual arising from each casualty, or from each theft, exceeds $\$ 100 . .$.

19. I.R.C. $§ 165(f)$ provides:

Capital Losses-Losses from sales or exchanges of capital assets shall be allowed only to the extent allowed in sections 1211 and 1212 .

20. I.R.C. \& $165(\mathrm{~g})$ provides:

Worthless Securities-

(1) General Rule-If any security which is a capital asset becomes worthless during the taxable year, the loss resulting therefrom shall, for purposes of this subtitle, be treated as a loss from the sale or exchange, on the last day of the taxable year, of a capital asset. 
require that the shareholder's loss receive capital loss treatment. ${ }^{21}$ Treatment as a capital loss involves several limitations ${ }^{22}$ which render the above provisions an ineffectual means of relief for the small investor. ${ }^{23}$ Capital loss treatment is unsatisfactory for the taxpayer who has little or no capital gains with which to offset a severe loss since such treatment may delay tax recovery for the loss and, in effect, render the taxpayer's assets inaccessible for an indefinite period of time. ${ }^{24}$

Another alternative is to allow the small investor a deduction against ordinary income for a theft loss, thereby enabling the taxpayer

21. There is a presumption that securities sold or exchanged are capital assets and as such are subject to capital gain or loss treatment. One exception to this presumption occurs when the taxpayer is a dealer, I.R.C. § 1221(1) defines one type of non-capital asset as stock in trade, inventory, or property held primarily for sale to customers. See J. ChOMmiE, Federal INCOME TAXAIION 374-75 (2d ed. 1973).

In an attempt to encourage investment in small business enterprise, small business corporation stock which becomes worthless during the taxable year is deductible in that year as against ordinary income. I.R.C. $\$ \$ 1242-1244$. See J. ChOMmIE, supra, at 382 . See also note 45 infra.

22. The first limitation is that capital losses are deductible to the extent that there are capital gains. I.R.C. § 1211(b)(l). However, if losses exceed gains, the Code authorizes a deduction against ordinary income, but not greater than $\$ 3,000$. I.R.C. $\S 1211$ (b)(2). For purposes of this section, taxable income is computed without regard to personal exemptions and without regard to capital gains and losses. I.R.C. \& 1211(b)(3). The computation calls for short-term loss to off-set taxable income on a dollar for dollar basis; long-term loss offsets taxable income on a two for one basis. I.R.C. § 1211. Lastly, a capital loss not offset in the current year is carried forward to the taxpayer's succeeding tax year and is treated as if it were actually realized in that succeeding year. I.R.C. § 1212(b).

23. Small investors generally do not have significant capital gains and a securities fraud frequently results in a drastic reduction of value. "While more than 27 million people do own some common stocks, still less than 1 in 10 gets an appreciable return." P. SAMUELSON, EconomICs 90 (8th ed. 1970). Moreover, the small investor represents a significant percentage of those 27 million people, as evidenced by recent studies which "show that in the typical giant corporation, all management together-officers and directors-holds only about 3 percent of the outstanding common stock. The largest single minority ownership groups typically hold only about a fifth of all voting stock." Id. In 1963, 84.5\% of the 200 largest corporations had no group of stockholders owning as much as $10 \%$ of the outstanding stock. Id. $90 \mathrm{n} .9$ (citing Larner, Ownership and Control. in the 200 Largest Nonfinancial Corporations, 1929 and 1963, 56 AM. Econ. REv. 778, 780 (1960)).

24. For example, suppose the taxpayer has no short-term or long-term capital gain (STCG or LTCG), no short-term capital loss (STCL), $\$ 100,000$ of long-term capital loss (LTCL) and $\$ 50,000$ taxable income. Under section $1211(b)(1)(C)$ the following computation results:

(Net STCL-Net LTCG) $=(0-0)=0$

plus

$1 / 2$ (Net LTCL-Net STCG) $=1 / 2(\$ 100,000-0)$ equals $\$ 50,000$.

Since long-term losses offset capital gains on a two to one ratio, the taxpayer's maximum deduction is $\$ 50,000$. However, in this example the taxpayer has no capital gains with which to offset the loss and must resort to section 1211(b)(2) which allows a deduction against taxable income not greater than $\$ 3,000$ for any given taxable year. Thus, in this hypothetical, the taxpayer is entitled to deduct $\$ 3,000$ from ordinary income. Under section 1212(b), the taxpayer is entitled to carry over $\$ 47,000$ to his next taxable year. However, given the same fact situation, the taxpayer again receives only a $\$ 3,000$ deduction from ordinary income and a carryover of $\$ 44,000$. Assuming that all other factors remain equal, it will take the taxpayer seventeen years to deduct the loss. 
to deduct a loss in the current year that is limited only by the taxpayer's income level. ${ }^{25} \mathrm{~A}$ loss from theft of an asset held less than one year is an ordinary loss. ${ }^{26}$ However, a theft loss of an income producing asset held for one year or more is subject to treatment under section 1231 as an involuntary conversion. ${ }^{27}$ Under 1231(a), total losses and gains resulting from involuntary conversions must be netted. If losses attributable to involuntary conversions exceed gains attributable to involuntary conversions, then, pursuant to a 1969 tax amendment, ${ }^{28}$ the net loss will be treated as an ordinary loss and section 1231 does not apply. ${ }^{29}$ If section 1231 does apply the net result is either a long term capital gain or an ordinary loss. ${ }^{30}$ However, in most casualty and theft loss cases, the losses usually exceed the gains, thereby circumventing section 1231 altogether and permitting taxpayer ordinary loss treatment. ${ }^{31}$ Thus, the theft loss deduction is more advantageous to the defrauded stockholder than are other Code provisions which offer only capital loss treatment.

Recently, the Internal Revenue Service (IRS) issued two revenue rulings concerning taxpayers who sought theft loss deductions for

25. This is in comparison with the capital loss provision which limits the deduction against ordinary income to $\$ 3,000$. See note 22 supra.

26. Under Section 1231, capital assets held for one year or less are distinguished from those held for more than one year, i.e, short-term capital assets as opposed to long-term capital assets. Section 1231 only discusses involuntary conversions as applied to long-term capital assets. I.R.C. \& 1231(a). Nonetheless, "[i]f a nonbusiness asset [nonbusiness assets may be capital assets] is held less than six months [one year as of 1978], an ordinary loss is available without being subject to the netting treatment of section 1231." Schwartz, Tax Losses: Casualty, Theft, Wagering, War and Expropriation in TAX LOSSES 62 (P. Berger ed. 1974). See also I.R.S. PuB. No. 547, TAX INFORmation on Disasters, Casuatty Losses and TheFTs $\llbracket 32,627$, at 8 (1978).

27. I.R.C. \& 1231(a).

28. Tax Reform Act of 1969, Pub. L. No. 91-172, \& 516(b), 83 Stat. 487, 646; See S. Rep. No. 552, 91st Cong., 1st Sess. 204-07, reprinted in [1969] U.S. CODE CoNG. \& AD. News 2027, 2239-41.

29. In the case of any involuntary conversion . . ., this subsection shall not apply to such conversion (whether resulting in gain or loss) if during the taxable year the recognized losses from such conversions exceed the recognized gains from such conversions.

I.R.C. $\$ 1231(\mathrm{a})$.

30. If gains from involuntary conversions exceed losses, then all such gains and losses are characterized as section 1231 gains or losses and are subject to section 1231 treatment. Under section 1231, all gains are totaled, as are all losses, i.e., section 1231 applies to gains or losses from sales or exchanges of property used in a trade or business and gain or loss recognized from the involuntary conversion of property used in a trade or business and the involuntary conversion of capital assets. If total section 1231 losses exceed total section 1231 gains, then all are charterized as ordinary gains and losses. However, if total section 1231 gains exceed total section 1231 losses, then all are characterized as capital gains and losses. Even though this last branch of involuntary conversion tax formula results in capital loss treatment of the taxpayer's theft loss, the taxpayer could not have reached such a point unless he had the gains with which to offset the loss. In other words, if a taxpayer must employ section 1231 treatment, the net result is either a long-term capital gain or an ordinary loss. I.R.C. \& 1231(a).

31. See J. CHOMmie, supra note 21 , at 358. 
losses attributable to a securities fraud..$^{32}$ In the first revenue ruling, ${ }^{33}$ the taxpayer purchased corporate stock through a public stock exchange and claimed that he had been induced to make such purchases as a result of the encouraging financial statements issued by corporate officers. ${ }^{34}$ After taxpayer's purchase, the SEC suspended trading in the corporation's stock because of insider manipulation of its market price. Investigation revealed substantial misstatements and fraudulent statements which had artificially inflated the stock's market price. ${ }^{35}$ The corporation's petition for bankruptcy was approved and the trustee reported to the court that there had been a securities fraud. ${ }^{36}$ The Service denied the theft loss deduction on the basis that the illegal activity engaged in by corporate officers did not fall within the definition of theft for federal income tax purposes. ${ }^{37}$ The Service noted that the taxpayer could not have been a victim of theft because he purchased his shares on the open market. Consequently, the perpetrators of the fraud did not have the requisite specific intent to defraud the taxpayer. ${ }^{38}$ Also, the Service implied that the value of stock could not be the subject of theft. ${ }^{39}$

In the second revenue ruling, ${ }^{40}$ the taxpayer purchased $100 \mathrm{x}$ shares of stock of the $Y$ corporation. Six years later, $Y$ 's board of directors approved an agreement and plan for merger with $X$ corporation. Pursuant to the agreement, $X$ provided $Y$ with detailed information about

32. Rev. Rul. 18, 1977-1 C.B. 46; Rev. Rul. 17, 1977-1 C.B. 44.

33. Rev. Rul. 17, 1977-1 C.B. 44. This first revenue ruling involved a fact situation similar to the one in the case of Paine v. Commissioner, 63 T.C. 736, aff d mem., 523 F.2d 1053 (5th Cir. 1975). As in the revenue ruling, the theft loss deduction was denied.

34. 1977-1 C.B. at 44-45. In Paine v. Commissioner, 63 T.C. 736, affd mem., 523 F.2d 1053 (5th Cir. 1975), the petitioner was unable to produce evidence showing that he had been induced to purchase Westec Corporation stock as a result of the financial statements issued. 63 T.C. at 742. See text accompanying note 153 infra.

35. The misstatements and fraudulent statements were as to (1) earnings and profits, (2) mineral discoveries, (3) acquisitions or sales of properties and (4) earnings projections. Various criminal indictments were returned against principal officers and employees of Westec. As a result of these indictments, the president of Westec pleaded guilty to conspiracy to violate the federal securities and mail fraud statutes. Other officers pleaded guilty to employing a manipulative and deceptive device in the purchase and sale of Westec stock, creating a false appearance of active trading that raised its price. 63 T.C. at 737-38.

36. The trustee in bankruptcy is required to report to the court any facts pertaining to fraud, misconduct, mismanagement or irregularities in the operation of the corporation. Section 167 of the Bankruptcy Act, 11 U.S.C. \& 567(3) (1970).

37. 1977-1 C.B. at 45.

38. "[T]he loss in value in taxpayer's stock does not come within the definition of theft, for Federal income tax purposes, because the perpetrators of the fraud at $\mathrm{X}$ [corporation] did not have the requisite specific intent to defraud the taxpayer and did not obtain possession and title to taxpayer's property." Id.

39. Id.

40. Rev. Rul. 18, 1977-1 C.B. 46. 
its financial condition that was included in the proxy statements sent to $Y$ 's stockholders. The agreement was approved by the shareholders, the merger was consummated, and taxpayer received shares of $X$ 's stock in exchange for $Y$ stock. Upon reports of irregular activities regarding $X$ corporation, all trading on public markets was suspended. The corporation's petition for bankruptcy was approved and the trustee reported to the court that there had been a securities fraud. ${ }^{41}$ The purpose of the fraudulent activities was to keep the price of $X$ 's stock aloft in order to clinch the merger. A class action was instituted consisting of all former stockholders of $Y$ corporation who sought to rescind the 1973 merger agreement because of the fraudulent inducement involved. In the second ruling, the IRS concluded that a theft had occurred within the bounds of federal income tax law, but denied the theft loss deduction on the ground that, since there was a reasonable prospect of recovering the loss, ${ }^{42}$ no portion of the loss was deductible under section 165. The Service ruled that a rescission of the $Y-X$ merger and consequent restoration of $Y$ stock to its former owners or bankruptcy reorganization served as a reasonable prospect of recovery. ${ }^{43}$

A recent IRS publication states that a theft loss deduction is allowed when a taxpayer can show that the taking of his property was illegal under the law of the state wherein it occurred and that the taking was done with criminal intent. ${ }^{44}$ Taxpayers in the two revenue rulings had claimed that a theft had occurred under state law. However, the thesis of this Comment is that theft loss deductions are appropriate for individual taxpayers who own securities which have declined in value as a proximate result of a federal securities law antifraud violation. ${ }^{45}$

\footnotetext{
41. See note 36 supra.
}

42. Treas. Reg. $\S 1.165-1(a)(2)(i)(1960)$ (theft loss is not deductible under section 165(a) if there is a reasonable prospect of recovery).

43. 1977-1 C.B. at 47.

44. I.R.S. Pub. No. 547, TAX Information on Disasters, Casualty Losses and TheFts I 32,621 (1978).

45. The primary focus of this Comment is on the public-issue corporation. An analysis of the applicability of the theft loss deduction to the close corporation is beyond the scope of this Comment. However, there may be some problems in applying the theft loss deduction to the close corporation. First, under federal income tax law, investors who have incurred a loss in small business stock already may be entitled to ordinary loss treatment. I.R.C. $§ 1244$. Subject to certain limitations, section 1244 allows an ordinary loss to individuals or partnerships on sales or exchanges (including transactions, such as where the taxpayer's stock holdings become worthless, treated as sales or exchanges) of "Section 1244 stock" that would otherwise be treated as a capital loss. I.R.C. \& 1244(a); Treas. Reg. \& 1.1244(a)-1(a) (1960). Section 1244(b) limits the amount of the deduction to $\$ 25,000$ (or $\$ 50,000$ for a joint return). "Section 1244 stock," however, has many limitations, some of which are that the corporation must adopt a plan to offer such stock for a period ending not later than two years after the date on which the plan was adopted, that the 
Consequently, this Comment will argue that the IRS's two rulings were wrongly decided. First, the definition of theft, for federal income tax purposes, does include violations of the federal antifraud provisions of the securities laws. Second, there exist identifiable events such that the theft loss deductions can be conveniently and appropriately timed. Third, these identifiable events are indicative of the fact that no reasonable prospect of recovery for the loss exists. Finally, the securities markets facilitate the measurement of the loss by providing reliable information as to security prices.

\section{Prelude to Defining Theft Loss: Policy Considerations}

In developing a rationale for personal expense deductions, Professor William $\mathrm{D}$. Andrews ${ }^{46}$ distinguished between a rationale which is based on income taxation objectives as opposed to one which is based on policies extraneous to the tax system itself. ${ }^{47}$ Professor Andrews' position is that a deduction is not justified unless based on a valid intrinsic policy consideration. ${ }^{48}$ Although extrinsic policy considerations are not irrelevant under Professor Andrews' analysis, such considerations are less important insofar as the objectives which they seek are best dealt with outside the taxation system. ${ }^{49}$ Nonetheless, both intrinsic and ex-

issuer must qualify as a small business corporation, that stock issued by the corporation pursuant to the plan must be issued for money or other property (not including stock and securities) and that the corporate issuer cannot have derived over $50 \%$ of aggregate gross receipts from sources other than royalties, rents, dividends, interest, annuities, and gains from sales or exchanges of stock or securities. I.R.C. $\$ 1244$ (c). The corporate issuer must keep detailed records to support its qualification as a small business corporation. See generally Treas. Reg. $\$ 1.1244$ (c)-1(a) (1960). Because of the limited availability of this provision, it arguably does not provide the taxpayer a remedy commensurate with an injury sustained as a result of a securities fraud. One cannot plan to be a victim of theft, yet, as demonstrated above, the taxpayer must meticulously plan to elect section 1244. Consequently, if a taxpayer were entitled to section 1244 ordinary loss treatment as relief for a securities fraud loss, such relief would be fortuitous.

Secondly, the relationship between a shareholder and a close corporation is very different from the relationship between a shareholder and a public-issue corporation. The shareholder in a close corporation is generally active in the management and operation of the business. Thus, in the close corporation there is a mixing of ownership and control, whereas ownership and control in the public-issue corporation are substantially separated. H. HENN, supra note $12, \S 257$, at 507. This distinction is significant to the extent that this Comment is concerned with the public-issue investor's serious disadvantage in dealing with persons possessing superior knowledge, skill and resources. See Chris-Craft Indus. v. Bangor Punta Corp., 480 F.2d 341, 357 (2d Cir.), cert. denied, 444 U.S. 910 (1973). The close corporation shareholder, on the other hand, has more of an opportunity to investigate statements by or about the corporation and thus his position may not warrant theft loss deduction relief.

46. Andrews, Personal Deductions in an Ideal Income Tax, 86 HARv. L. REv. 309 (1972).

47. Id. 312 .

48. $I d$.

49. Id. 311. See also Note, Defining "Medical Care": The Key to Proper Application of the 
trinsic policy considerations buttress the allowance of a theft loss deduction.

\section{A. The Intrinsic Policy Justification.}

One goal of taxation is "to distribute the cost of government fairly by income classes (vertical equity) and among people in approximately the same economic circumstances (horizontal equity)." ${ }^{50}$ Professor Andrews reformulated this goal as follows: A tax deduction may be justified by demonstrating that the deduction "effectuates intrinsic personal income tax ideals by insuring that only 'real income' comprises the income tax base." ${ }^{\text {II }}$ In other words, it is only by determining the appropriate income base that the taxpayer is fairly taxed.

In this analysis, Professor Andrews used Henry Simons' definition of "real income" as the sum of aggregate personal consumption during the taxable year, plus the change in taxpayer's accumulation of goods and services between the beginning and end of the taxable year. ${ }^{52}$ Simons' theory defines income in terms of uses, instead of defining it in terms of sources. ${ }^{53}$ Clearly, there are two uses for money, namely, consumption and saving. ${ }^{54}$ The first element in Simons' definition, however, includes "all the taxpayer's ultimate, potentially beneficial expenditures made as a result of personal choices from among the many gratifications (goods or services) available in the distributive sector." 55 In other words, the consumption component encompasses only that which the taxpayer voluntarily consumes as opposed to personal consumption as to which the taxpayer either actually or effectively has no choice. The second element represents savings since it includes all the additions to the taxpayer's accumulated wealth. ${ }^{56}$ Professor Andrews views the intrinsic role of personal deductions as compensation to the taxpayer whenever money is expended for anything other than

Medical Expense Deduction, 1977 Duke L.J. 909, $911-12$ (discussing Professor Andrews' theory as applied to the medical expense deduction).

50. J. Pechman, Federal Tax Policy 5 (Brookings Institution 1966).

51. Note, supra note 49, at 911. See Andrews, supra note 46, at 330.

52. "Personal income may be defined as the algebraic sum of (1) the market value of rights exercised in consumption and (2) the change in the value of the store of property rights between the beginning and end of the period in question." H. Simons, Personal InCOME TAxation 50 (1938).

53. Andrews, supra note 46 , at 320 .

54. P. SAMUELSON, supra note 23, at 193-207. "Income is one of the most important determinants of consumption (food, clothing, total) and of savings." Id. 206.

55. Note, supra note 49, at 912. For an explanation of this first element see Andrews, supra note 46, at 320-22; Note, supra note 49, at 912-13.

56. Andrews, supra note 46 , at $320-22$. 
personal consumption and savings. ${ }^{57}$ Thus, for example, the medical expense deduction is intrinsically sound, since extraordinary medical expenditures are involuntary, intermediate expenditures which are not included in the Simons' definition of real income but which nonetheless reduce money income. ${ }^{58}$ Likewise, the theft loss deduction may be justified by reference to intrinsic matters of tax policy.

The theft loss deduction and the medical expense deduction are parallel in several respects in that they both compensate for events which are unusual, involuntary, unpredictable and may exhaust a large proportion of the taxpayers' total income in a particular year. ${ }^{59} \mathrm{Clearly}$, loss due to theft is not included in the Simons' definition of personal consumption. Aggregate personal consumption is that component of real income which accounts for expenditures. However, the victim of a theft has involuntarily parted with his property and, in fact, has consumed nothing. ${ }^{60}$ Thus, such an expenditure cannot properly be included in a taxpayer's income base. The accumulation of goods and service component does not include taxpayer's theft loss since it accounts solely for the accretion of wealth. Thus, theft losses do not reduce the real income base despite the fact that such losses actually reduce money income. Consequently, a deduction is necessary in order to compensate the taxpayer for the loss, thereby returning the taxpayer to the real income base from which his taxes may be fairly assessed.

\section{B. The Extrinsic Policy Justification.}

Despite the fact that Professor Andrews views extrinsic policy considerations as inadequate justifications for a deduction, the tax system does not operate in a void, and its effect on other societal concerns cannot be ignored. The predicament of the shareholder must be realistically examined, thereby requiring analysis not only from the viewpoint of tax law, but from the viewpoint of securities law as well.

A Treasury Regulation disallows a deduction for a decline in the value of stock "when the decline is due to a fluctuation in the market price of the stock or other similar causes." recognition rule is the worthless securities deduction, which was mentioned earlier. ${ }^{62}$ An extrinsic policy consideration in justification of the

57. Id. 330.

58. Note, supra note 49, at 913.

59. J. PeCHMAN, supra note 50, at 76.

60. See, e.g., S. 1437, 95th Cong., 1st Sess. (1977) (proposed federal criminal code) ("§ 1731. Theft-(a) Offense-A person is guilty of an offense if he obtains or uses the property of another with intent: (1) to deprive the other of a right to the property or a benefit of the property.").

61. Treas. Reg. \& 1.165-4 (1960).

62. I.R.C. § $165(\mathrm{~g})$. See note 20 supra and accompanying text. 
worthless securities deduction is the promotion of economic growth. ${ }^{63}$ By allowing the taxpayer a deduction, Congress has provided him a tax incentive for future investment. ${ }^{64}$ This rationale is also applicable to the theft loss deduction.

However, a theft loss would provide the taxpayer with ordinary loss treatment as opposed to capital loss treatment which is available under the worthless securities provision. The rationale for allowing ordinary loss treatment is dependent upon a comparison between tax law provisions and securities law provisions with the objective of making the policies underlying those provisions, as well as the provisions themselves, consistent with one another.

Securities law provides the shareholder with an implied civil remedy for damages when that shareholder has suffered a loss as a proximate result of a $10 \mathrm{~b}-5$ violation. ${ }^{65}$ Securities law does not provide similar relief for loss due to poor business judgment. The premise in this Comment is that a decline in the value of stock which proximately results from a federal securities law antifraud violation is not due to the usual risks of the marketplace. Instead, the loss is the direct result of another's illegality; and it is a generally accepted maxim in the law that one does not assume the risk of another's illegality. ${ }^{66}$

Tax law, on the other hand, provides tax relief in the form of capital loss treatment for realized losses (including worthlessness) even if the cause of that loss was the poor business judgment of the investor. Since securities law recognizes that victims of fraud are entitled to special consideration, it seems only consistent with securities law policies that tax law also afford the victim of fraud special consideration via the ordinary loss treatment available under the theft loss provision. Moreover, as will be demonstrated, the theft loss provision, using the federal income tax definition of theft, already encompasses the securities fraud situation.

\section{The Definition of ThefT}

The term "theft" is not defined in the Code. Moreover, the theft loss deduction, which first appeared in the Revenue Act of $1916,{ }^{67}$ has virtually no legislative history on which to rely for interpretive pur-

63. J. Pechman, supra note 50, at 5 .

64. See Andrews, supra note 46, at 311 \& n.4. See also Note, supra note 49, at 911.

65. Kardon v. National Gypsum Co., 69 F. Supp. 512 (E.D. Pa. 1946).

66. See W. Prosser, LAW OF TORTS \& 33, at 173-74 (4th ed. 1974).

67. Revenue Act of 1916, ch. 463, \& 5(a)(4), 39 Stat. 759. For background on I.R.C. \& 165(c)(3), see Note, The Casualty Loss Deduction and Consumer Expectation: Section 165(c)(3) of the Internal Revenue Code, 36 U. CHI. L. REv. 220 (1968). 
poses. ${ }^{68}$ The regulations merely state the open-ended definition that "theft" is "deemed to include but shall not necessarily be limited to, larceny, embezzlement, and robbery." ${ }^{\prime 69}$ A recent IRS publication has defined theft, for federal income tax purposes, as a taking of property illegal under the law of the state wherein the taking occurred if that taking was done with criminal intent. ${ }^{70}$ An examination of the tax law of theft loss deductions reveals that the IRS, by requiring that the taking be illegal under state law, has incorrectly stated the tax law definition of theft.

As will be demonstrated, the proper definition requires only that the taking was illegal under the law of the jurisdiction wherein the taking occurred and that the taking was committed with criminal intent. Furthermore, recent cases in the securities area recognize that "value" can be the object of a criminal "taking." By applying the correct tax law definition of theft it is clear that the federal antifraud provisions of the 1934 Securities Exchange Act are included within that definition.

\section{A. Must the Taking Be Illegal Under State Law?}

The case most frequently cited for a definition of theft is Edwards

68. Note, supra note 67, at 220. "[T] he term 'theft' . . . appears to have been added to section 165 (c)(3) as an afterthought." Note, Federal Income Tax: The Dilemma of the Casualty Loss Deduction, 1961 DuKE L.J. 440, 443-44. "There is no recorded explanation of the justification for many of the personal deductions. Most of them have been allowed since the beginning of the income tax." J. PECHMAN, supra note 50 , at 76.

The fourth recommendation of the Committee was that individuals be permitted to deduct all losses. . . . The intent of this recommendation was that the law should recognize losses other than those incurred strictly in connection with the business or trade of the taxpayer, such as losses of property used for investment or speculative purposes.

National Tax Ass'N, Proceedings of the 10Th National Conference 185-86 (app.) (1916) (statement of the provisions of the Revenue Act of 1916). "The most likely explanation is simply that Congress was actuated by a notion of fairness; it sought to reduce the tax burden on a person whose income does not reflect his economic position because his assets have been destroyed during the taxable year." Note, supra note 67, at 220.

Moreover, there has been very little written about the theft loss provision. The following are the only available sources specifically focusing on the theft loss deduction: Geller \& Rogers, Embezzlement Has Its Tax Problems, Too, 26 TAxes 1097 (1948); Stuetzer, Embezzlement Losses: Time for Deduction, 4 TAx L. Rev.195 (1949); Note, Income Tax Consequences of Theft, 35 VA. L. REV. 759 (1949); 10 VAND. L. REV. 153 (1956) (four-page analysis of Edwards v. Bromberg, 232 F.2d 107 (5th Cir. 1956)).

Perhaps one explanation for this dearth of analysis is that deductions for theft and casualty combined are quantitatively unimportant as compared to total personal deductions. See C. KAHN, Personal Deducations in the Federal Income Tax 159-61 (1960). As of 1956, deductions claimed for personal property losses resulting from theft and casualty never amounted to much more than one percent of total personal deductions. Id. 159.

69. Treas. Reg. $\$ 1.165-8$ (d) (1960).

70. I.R.S. Pub. No. 547, TaX Information on Disasters, Casualty Losses and Thefts \32,621 (1978). 
v. Bromberg..$^{71}$ In that case, a person receiving money from a taxpayer under the fraudulent pretense that it would be bet on a horse race embezzled the money. In granting the taxpayer's claim for a theft loss deduction, the Court of Appeals for the Fifth Circuit emphasized the wide spectrum of acts which are incorporated under the term "theft" for purposes of federal income tax law. The court stated that theft is "a word of general and broad connotation, intended to cover and covering any criminal appropriation of another's property to the use of the taker, particularly including theft by swindling, false pretenses, and any other form of guile." A2 Along the same line, the court stated that "the exact nature of the crime. . . is of little importance so long as it amounts to theft." 73

More importantly, the court also held that whether a loss from theft occurs depends upon the law of the jurisdiction wherein it occurred.$^{74}$ Courts have repeatedly cited this proposition and have proceeded to apply state law without further discussion. ${ }^{75}$ It might be argued therefore that they have construed "law of the jurisdiction" to mean only "state law." This is the position the IRS has taken, ${ }^{76}$ apparently excluding federal criminal statutes from the concept of "law of the jurisdiction." However, it must be noted that the courts have never been required to reach the issue of whether a federal statute meets the tax law definition of theft. ${ }^{77}$ Therefore, there has been no discussion of

71. 232 F.2d 107 (5th Cir. 1956). For an analysis of Edwards, see 10 VAND. L. REv. 153 (1956).

72. 232 F.2d at 110 (footnote omitted).

73. Id. at 111 .

74. Id. See also J. CHOMmie, supra note 21 , at 160 ("the courts have not limited the concept of a theft to its common law meaning but have held that it embraces thefts as defined by statute.").

75. Howard v. United States, 497 F.2d 1270, 1272-73 n.4 (7th Cir. 1974), aff 32 A.F.T.R.2d (P-H) 73-5753 (1973) (theft as defined by Illinois statutes); Estate of Max Shlensky, 36 T.C.M. (CCH) 628, 631 (1977); Joseph M. Sperzel, 52 T.C. 320, 328 (1969) (petitioner's evidence did not establish a violation of New York's criminal laws); Robert S. Gerstell, 46 T.C. 161, 172 (1966) (theft as defined by Pennsylvania law); Michele Monteleone, 34 T.C. 688, 692 (1960) (citing to Edwards, then defining theft under California Penal Code).

The Edwards majority cited Borden v. Commissioner, 101 F.2d 44 (2d Cir. 1939). In Borden, the court concluded that a theft occurred under state law without explaining why it looked to state law in the first place. Similarly, the Edwards court cited Morris Plan Co., 42 B.T.A. 1190 (1940), acq., 1941 I.R.B. 8, wherein the court made the unexplained assertion that state law determined whether a theft had occurred. 42 B.T.A. at 1195 . Ironically, the Morris case is frequently cited as authority for this assertion. E.g., Michele Monteleone, 34 T.C. 688, 692 (1960); J.H. McKinley, 34 T.C. 59, 62 (1960). See also McComb v. Commissioner, 36 T.C.M. (CCH) 725, 729 (1977); Paul C.F. Vietzke, 37 T.C. 504, 510 (1961) (Monteleone cited for same proposition).

76. See, e.g., Rev. Rul. 381, 1971-2 C.B. 126; Rev. Rul. 215, 1977-1 C.B. 52 ("The transaction was, under local law, the crime of larceny"); I.R.S., PuB. No. 547, TAX INFORMATION ON Disasters, Casualty Losses and Thefts $\{32,621$, at 1 (1978).

77. Cf. Curtis H. Muncie, 18 T.C. 849 (1952) (court looked to the Mexican law definition of theft-since the taxpayer had been swindled in Mexico-and concluded that the taxpayer had 
the applicability of federal criminal laws, much less a decision on this point.

Properly understood, the Edwards proposition seems unassailable. It simply asserts that the proper laws to be consulted are those that were actually relevant to the protection of the taxpayer's property. For example, if property is taken in North Carolina, then it would be inappropriate to consider whether the taking would have been illegal in Delaware. However, in determining whether the property is protected by virtue of a criminal theft statute, there is no reason to limit the inquiry solely to state criminal law. Neither the Code nor logic supports the proposition that Congress intended to distinguish takings that are illegal under state law from takings that are illegal under federal law.

The respective powers of the state and federal governments are such that state law is the primary law governing most theft situations. ${ }^{78}$ However, in certain situations the federal government has the power to create statutory crimes, ${ }^{79}$ and it has availed itself of that power in the area of securities marketing. ${ }^{80}$ Professor Louis Loss has stated that a federal-state dichotomy has developed in corporate law; state statutes are concerned primarily with the internal structure and workings of the corporation whereas federal law is dominant in the antifraud aspect of

indeed suffered a theft as far as tax law was concerned). In the more recent case of Perry $A$. Nichols, 43 T.C. 842 (1965), the tax court noted in dictum that the unlawful activity was proscribed not only by state law but by federal law as well. Id. at 884-85. See also Annot., 62 A.L.R.2d 572, 578 (1958) (statement that whether a loss is due to theft under federal income tax law depends upon the state or nation in which the theft occurred).

78. A state has broad authority to define what acts are criminal pursuant to its police power. "The police power of a state today embraces regulations designed to promote the public convenience or the general prosperity as well as those to promote public safety, health, and morals, and is not confined to the suppression of what is offensive, disorderly, or unsanitary, but extends to what is the greatest welfare of the state." Congressional Research Service, The Constitution of the United States of AMerica, ANalysis and InTERPRetation, S. Doc. No. 92, 92d Cong., 2d Sess. 1317 (1972). State law is primary regarding the definition of theft since the federal government has no such broad police power to regulate and prescribe punishment. See W. LAFAVE \& A. Scotr $\S 16$, at 107 .

79. The federal government has the power to create statutory crimes in two situations: first, when the Constitution expressly grants Congress such power, e.g., U.S. CoNST. art. I, \& 8 (power to punish counterfeiting, piracies, felonies on high seas, offenses against the law of nations); art. III, $\S 3$ (power to punish treason); and second,when the Constitution gives Congress the power to do what is "necessary and proper," U.S. CoNST. art. I, § 8, cl. 18, to carry out expressly conferred powers, such as the power to regulate interstate commerce, to establish post offices, to tax, etc., W. LAFAVE \& A. ScotT $\S 16$, at 112.

80. The growth of the federal criminal law is partially attributable to the general increase of federal regulation which is apparent in the areas of interstate transportation, communications, wholesomeness of food, marketing of securities, labor relations, etc. See generally Schwartz, Federal Criminal Jurisdiction and Prosecutor's Discretion, 13 LAw \& CoNTEMP. PROB. 64 (1948). 
corporation law. ${ }^{81}$ In fact, new state corporation statutes are not at all concerned with Rule 10b-5-type problems. ${ }^{82}$

Significantly, a major reason given for the enactment of the federal securities laws was a belief that the states had failed to provide adequate criminal and civil laws to protect the property interests of investors in their investments. ${ }^{83}$ By enacting section $10 \mathrm{~b}$ of the 1934 Securities Exchange Act, ${ }^{84}$ Congress has indicated that shareholders' property interests are important and worthy of protection. ${ }^{85}$ Thus, federal laws which simply augment state criminal laws on illegal takings ought to be treated the same as state laws for purposes of the federal income tax.

\section{B. Theft of "Value."}

The Securities Exchange Act of $1934^{86}$ was enacted to regulate the securities markets and activities of broker-dealers for the protection of investors. ${ }^{87}$ Under section 32, Congress authorized the imposition of criminal sanctions for violations of either the Act or the rules and regu-

81. See Loss, The American Law Institute's Federal Securities Code Project, 25 Bus. Law. 27 (1969):

It is only realistic to recognize that over the last few decades we have been developing a federal corporation law under the aegis of 10b-5, primarily, and the proxy rules, and that gradually we seem to be developing a federal-state dichotomy in corporation law, so that the state statutes seem to be concerned primarily with the internal structure and workings of the corporation, while we are leaving to the federal law the very important aspect of corporation law that is represented by the fiduciary duty of management, of directors, and so on.

Id. 34. See also Carey, Federalism and Corporate Law: Reflections Upon Delaware, 83 YALE L.J. 663,693 (1974) ("Suffice it to say that there has been an explosive development of the law based upon a few phrases in $\S 10(\mathrm{~b})$ and Rule 10b-5"). But see Sante Fe Industries v. Green, 430 U.S. 462, 479 (1977) (citing with disapproval Carey, supra at 700).

82. 'New corporation statutes don't concern themselves very much with the 10b-5 type of problems-fiduciary problems of that sort-and deal not at all with proxy solicitation, but concern themselves with the internal ordering of the corporation primarily." Loss, supra note 81, at 34. However, in Sante Fe Industries v. Green, 430 U.S. 462 (1977), the Supreme Court specifically refrained from expanding Rule 10b-5 to include regulation of "transactions which constitute no more than internal mismanagement." Id. at 479 (citing Superintendent of Ins. v. Bankers Life \& Cas. Co., 404 U.S. 6, 12 (1971)). The Sante Fe Court stated: "We are reluctant to federalize the substantial portion of the law of corporations that deals with transactions in securities, particularly where established State policies of corporate regulation would be overridden." 430 U.S. at 479.

83. See 1 A. BROMBERG § 2.7(1)-(2).

84. See note 9 supra.

85. "The 1934 Act was intended principally to protect investors against manipulation of stock prices through regulation of transactions upon securities exchanges and in over-the-counter markets, and to impose regular reporting requirements on companies whose stock is listed on national securities exchanges." Ernst \& Ernst v. Hochfelder, 425 U.S. 185, 195 (1976) (citing S. REP. No. 792, 73d Cong., 2d Sess. 1-5 (1934)).

86. 15 U.S.C. $\$ \S 78 \mathrm{a}-78 \mathrm{kk}(1976)$.

87. The 1934 Act also established the SEC, which in turn promulgates rules and regulations. 15 U.S.C. $\S 78 \mathrm{~d}(\mathrm{a})$ (1976). 
lations promulgated pursuant to it. ${ }^{88}$ Certain provisions of the 1934 Act render unlawful a type of conduct which, in fact, results in an unlawful taking of property as interpreted under the tax law definition of theft. Section $10(b)$ is a general antifraud provision which makes unlawful the use of any manipulative or deceptive device or contrivance in connection with the purchase or sale of any security.$^{89}$ Rule $10 \mathrm{~b}-5$ prohibits (1) the employment of any device, scheme or artifice to defraud; (2) any misstatement or omission of material fact; and (3) any act, practice or course of business which operates as a fraud or deceit, in connection with the purchase or sale of any security. ${ }^{90}$

When a person purchases or sells in the securities market he has parted with property, namely, money or stock. However, when that purchase or sale is tainted by a $10 \mathrm{~b}-5$ violation, the innocent party has been unlawfully deprived of his property and the defrauded purchaser or seller of stock has an implied direct right of action under section 10(b) and Rule 10b-5.91 The effective deprivation need not always occur in the purchase or sale, but may also occur in the decrease in the value of the asset which frequently accompanies the $10 \mathrm{~b}-5$ violation. Clearly, stocks and bonds are property subject to theft under modern criminal statutes. ${ }^{92}$ However, in a securities fraud context, the value of stock may also be the subject of an unlawful taking.

The United States Supreme Court recognized this fact in Blue Chip Stamps v. Manor Drug Stores..$^{93}$ In Blue Chip the Supreme Court affirmed the ruling in Birnbaum v. Newport Steel Corp..$^{94}$ that in order to have standing to sue for direct relief under Rule $10 \mathrm{~b}-5$, the plaintiff must have been a purchaser or seller of securities. The Court based its decision on legislative history, lower court decisions, and policy considerations regarding strike suits and otherwise vexatious litigation. ${ }^{95}$ However, the Court recognized a major failure of the Birnbaum rule: "The Birnbaum rule undoubtedly excludes plaintiffs who have in fact been damaged by violations of Rule $10 \mathrm{~b}-5$, and to that extent it is unde-

88. 15 U.S.C. $\$ 78 f$ (1976) $(\$ 10,000$ fine or five years imprisonment or both).

89. 15 U.S.C. $\$ 78 \mathrm{j}(\mathrm{b})(1970)$.

90. 17 C.F.R. \& 240.10b-5 (1977).

91. See note 8 supra and accompanying text. "Although $\S 10(b)$ does not by its terms create an express civil remedy for its violation, and there is no indication that Congress, or the Commission when adopting Rule $10 \mathrm{~b}-5$, contemplated such a remedy, the existence of a private cause of action for violations of the statute and the Rule is now well established." Ernst \& Ernst v. Hochfelder, 425 U.S. 185, 196 (1976).

92. See W. LAFAve \& A. SCOTT $\$ 90$, at 665 .

93. 421 U.S. 723 (1975).

94. 193 F.2d 461 (2d Cir.), cert. denied, 343 U.S. 956 (1952).

95. 421 U.S. at $740-45$. 
sirable."966 There are three classes of plaintiffs to which the Birnbaum rule effectively denies a remedy: first, those "who allege that they decided not to purchase because of an unduly gloomy representation or the omission of favorable material"; second, "actual shareholders in the issuer who allege that they decided not to sell their shares because of an unduly rosy representation or a failure to disclose unfavorable material"; and third, "shareholders, creditors, and perhaps others related to an issuer who suffered loss in the value of their investment due to corporate or insider activities in connection with the purchase or sale of securities which violate Rule 10b-5."97

Theft loss deductions should not be made available to shareholders in the first category since such an application of the deduction would speculatively compensate the taxpayer for gain not received, as opposed to an actual loss. However, for shareholders in the second and third categories the theft loss'deduction would serve as a legitimate and justifiable remedy. In recognition of the actual loss incurred by these shareholders, the Court of Appeals for the Second Circuit in Schoenbaum v. Firstbrook ${ }^{98}$ held that one way they may circumvent the Birnbaum doctrine is by bringing a derivative action so long as the corporate issuer is itself a purchaser or seller of securities. Judicial recognition of the loss incurred by these shareholders and the subsequent attempt to afford a substituted remedy support the view that it is also the value of the stock which is the subject of the unlawful taking under the federal securities laws, not simply the title to the stock.

In summary, when a 10b-5 violation has occurred in connection with the purchase or sale of any security ${ }^{99}$ an unlawful taking of property has simultaneously occurred. Thus, when a shareholder claims a loss due to a securities fraud he is also alleging that an unlawful taking of property has occurred under federal law. However, such an allegation represents only the first part of tax law's bifurcated test for determining whether a theft has occurred. The second part of the test requires the taxpayer to allege that the taking was done with criminal intent. ${ }^{100}$

96. Id. at 743 .

97. 1 d. at $737-38$.

98. 405 F.2d 215, 219 (2d Cir. 1968), cert. denied, 395 U.S. 906 (1969); see Note, Recklessness Under Section 10(b): Weathering the Hochfelder Storm, 8 RuT.-CAM. L.J. 325, 330 n.32 (1977).

99. In other words, if a taxpayer is a holder of stock in a corporation in which there has been a 10b-5 violation and has suffered damage as a result of the fraud, he need only show the IRS that the fraud was in connection with a purchase or sale of some security. The taxpayer need not be a purchaser or seller of a security in order to take the theft loss deduction.

100. See, e.g., Johnson v. United States, 291 F.2d 908, 909 (8th Cir. 1961) (income tax definition of theft "consist[s] only of takings and deprivations in which the element of criminal intent has been involved."). 


\section{The Requirement of Criminal Intent.}

An examination of the tax law of theft loss deductions reveals that the law of the jurisdiction, whether state or federal, is not to be consulted to determine the requisite mental state. For example, petitioners in Bellis v. Commissioner ${ }^{101}$ sought to deduct the loss on their investment in a Las Vegas casino. The stock they purchased had not been registered for sale by the SEC or the California Corporation Commission. The tax court denied the deduction on the ground that petitioners failed to show that the wrongdoers had the requisite criminal intent. ${ }^{102}$ The court required a showing of criminal intent even though the crime alleged under the California Corporations Code was a strict liability offense; the wrongdoer's mental state is irrelevant. ${ }^{103}$ Other cases support the assertion that the criminal intent element is a separate and distinct part of the tax law definition of theft. ${ }^{104}$ Thus, tax law has its own definition of theft, and the tax court recognized that fact in Bellis when it denied a theft loss deduction to one taxpayer by asserting that "petitioner does not reach the threshold point of our broad definition of theft." 105 This line of cases further illustrates that the law of the jurisdiction is to be consulted only with regard to the definition of an unlawful taking.

\section{The Timing of the Deduction}

After satisfactorily alleging both parts of the above test, the taxpayer must be able to point to some identifiable event which marks his discovery of the theft and which demonstrates the accuracy of the alle-

101. 61 T.C. 354 (1973), affd, 540 F.2d 448 (9th Cir. 1976).

102. "Without evidence of guilty knowledge or intent ... petitioner does not reach the threshold point of our broad definition of theft." 61 T.C. at 357.

103. "California sanctions against selling stock without a permit apply strictly to every such seller whether he merely makes an honest mistake or is engaged in a malignantly fraudulent scheme." Id. See CAL. CoRP. Code $\$ 26104$ (West 1968) (now codified in CAL. CoRp. Code $\S \S$ 25166, 25216, 25245, 25400, 25401, 25540, 25541 (West 1977)).

104. See, e.g., Farcasanu v. Commissioner, 436 F.2d 146 (D.C. Cir. 1970), aff'g per curiam, 50 T.C. 881 (1968). In Farcasanu, the circuit court stated:

It is also true that the law of the situs of the taking has generally been the governing standard for the determination of illegality . . . . However, the courts in construing this provision have consistently required that the taking be accompanied by criminal intent in order to render the taxpayer's loss deductible under section 165.

436 F.2d at 149. For an example of an older decision asserting the same basic proposition, see Morris Plan Co., 42 B.T.A. 1190, 1195 (1940) ("Clearly there was an intent by the wrongdoer to convert it; and it seems equally clear that the conversion was accomplished.").

105. 61 T.C. at 357. The Ninth Circuit affirmed, 540 F.2d 448 (9th Cir. 1976), and reiterated the tax court's statement. Id. at 449. See also Annot., 62 A.L.R.2d 572, 579 (1958) (separating the analysis of the requisite mental state from the analysis of the definition of theft). 
gation. ${ }^{106}$ The relationship between the shareholder and the public-issue corporation is principally controlled by intermediaries. ${ }^{107}$ Consequently, those events which pinpoint the year of the loss in the typical theft situation are inapplicable to the securities fraud situation. ${ }^{108}$ There are, nevertheless, reliable identifiable events which not only pinpoint the time of the theft but also constitute prima facie evidence that both parts of the theft loss deduction test have been met. These are certain enforcement actions instituted by the SEC and by private litigants.

Theft losses are deductible only in the year in which taxpayer discovers the loss. ${ }^{109}$ The loss is considered discovered when a reasonable man under similar circumstances would have become aware of the loss. ${ }^{110}$ Prior to the 1954 Code, the timing rule for theft loss deductions was the same as that for casualty loss deductions, that is, all section 165(c)(3) losses were deductible in the year in which the loss was sustained. ${ }^{111}$ However, as tax law developed, it became evident that the theft loss deduction required separate treatment. In Alison $v$. United States, ${ }^{112}$ the petitioner had been a victim of embezzlement for eight years but failed to discover the embezzlement until the eighth year. The effect of this delay in discovery of the loss would have been to deny taxpayer tax relief for several years of losses, since the taxpayer has only three years within which to file an amended tax return. ${ }^{113}$ Nonetheless, the deduction was allowed in the year the loss was discovered on the basis that the "essence of embezzlement" was secrecy and that to deny the deduction would impose undue "hardship and injustice."114 Consequently, when Congress reformed the tax code in 1954, section 165(e) was added which provided that for all losses due to theft, the year of discovery was the only year in which the theft loss could be deducted. ${ }^{115}$ Apparently, one reason Congress applied the rule to all

106. An identifiable event fixes the appropriate time for taking the deduction. Boston Consol. Gas Co. v. Commissioner, 128 F.2d 473 (Ist Cir. 1942).

107. This Comment focuses on the public-issue corporation. See note 45 supra.

108. See text accompanying notes 3-5 supra.

109. I.R.C. \& $165(\mathrm{e})$.

110. Cramer v. Commissioner, 55 T.C. 1125,1134 (1971).

111. H.R. Rep. No. 1337, 83d Cong., 2d Sess. A46 (1954).

112. 344 U.S. 167 (1952).

113. Id. at 168 .

114. Id. at 169. See also Rev. Rul. 183, 1953-2 C.B. 143, in which the IRS echoed the Alison case by stating that "the facts reveal that undue hardship or injustice would result if the loss were allowed only in the years the embezzlement occurred." Id. at 143.

115. H.R. Rep. No. 1337, supra note 111, at A46. See generally 5 J. Mertens, Federal INCOME TAXATION $\S 8$ 165, 201-202 (1975); see also Asphalt Indus. v. Commissioner, 411 F.2d 13 (3d Cir. 1969); Jane U. Elliot, 40 T.C. 304 (1963). Cf. Treas. Reg. § 1.165 8(b) (1960) (providing for an exception to the rule as applied to estates). 
theft loss deductions rather than just embezzlement was that there were other theft crimes capable of being concealed. ${ }^{116}$ Although Congress may not have had the securities markets in mind, the timing rule facilitates the application of the theft loss deduction to the securities fraud case because most shareholders will not discover that an unlawful activity has allegedly occurred until the SEC has brought such information to light.

\section{A. Identifiable Events in Securities Frauds.}

The formal events by which a reasonable shareholder discovers (either actually or constructively) that he has been the victim of a securities fraud are the initiation of enforcement action either by the SEC or by private litigants seeking direct relief. However, these events do more than merely pinpoint the year of discovery. Further examination of the tax law of theft loss deductions leads to the conclusion that these events actually constitute adequate evidence for the two-part definition of "theft."

Tax law does not require that the victim of a theft pursue any criminal or civil remedies in order to take the theft loss deduction. ${ }^{117}$ In Bromberg, the Court of Appeals for the Fifth Circuit rejected the IRS argument that "in order for a taxpayer to claim a deduction for a loss from theft, he must show that he has made an effort to and cannot obtain restitution." 118 The court further stated:

The [theft statute under the law of the jurisdiction] makes no such requirement, and when the nature of the matter dealt with, thieving and thievery, is considered, it seems clear, we think, that only if there were a specific provision imposing this requirement, would a court be authorized to hold that it exists. ${ }^{\text {ng }}$

In Michele Monteleone, ${ }^{120}$ a taxpayer brought both criminal and civil proceedings against an alleged swindler whose occupation was to promote and manage night clubs, restaurants and cocktail lounges. The defendant stipulated to plaintiff's allegations in the civil proceedings claiming that he wanted to return the money, ${ }^{121}$ and the criminal in-

116. "In embezzlement and other losses, however, the taxpayer may not find out about the loss until the statute of limitations has run for the year in which the loss was incurred." H.R. REP. No. 1337 , supra note 111 , at 46 (emphasis added).

117. However, failure to accuse suspects or to report the theft to the police has been held to be a factor against the taxpayer's claimed theft loss. See Sidney Lemmon, 27 T.C.M. (CCH) 503 (1968). But see Frederick C. Moser, 18 T.C.M. (CCH) 116 (1950), where such failure was satisfactorily explained.

118. $232 \mathrm{~F} .2 \mathrm{~d}$ at 111 .

119. Id.

120. 34 T.C. 688 (1960).

121. The defendant's explanation for stipulating to civil liability is very unclear. Id. at 693 
dictment was dismissed for lack of probable cause. ${ }^{122}$ Nevertheless, the tax court allowed the taxpayer a theft loss deduction, stating that the defendant's stipulation in the civil proceedings was sufficient proof of theft and that the taxpayer was only required to prove that the loss was "occasioned by circumstances clearly indicating theft." 123 The result of the court's holding is that a theft loss deduction may be granted when the evidence of theft is incomplete. Thus, the dual significance of the "identifiable events"-SEC enforcement action and private litigants seeking direct relief-is that they pinpoint the year of discovery and serve as proof that a loss was "occasioned by circumstances clearly indicating theft."

1. Private Litigation as an Identifiable Event. A shareholder who institutes a private action seeking direct relief under Rule 10b-5 must meet five criteria in order to have standing to sue. First, the plaintiff must have been a purchaser or seller of stock. ${ }^{124}$ Second, the defendant must have employed a manipulative or deceptive device. ${ }^{125}$ Third, the deception must go to some material fact. ${ }^{126}$ Fourth, the plaintiff's reliance on such deception must have caused the damage. ${ }^{127}$

n.3. See Spiegel v. United States, 75-2 U.S. Tax Cas. (CCH) If 9667, at 88,026 (S.D. Fla. 1975) (taxpayer not entitled to a theft loss since the thief compensated taxpayer with two promissory notes and a professed intent and ability to repay).

122. 34 T.C. at 694 .

123. Id. (citing Warner L. Jones, 24 T.C. 525 (1955)). In Monteleone, the tax court also stated that "a criminal conviction is not a necessary element in a taxpayer"s proof in this Court that a theft loss has been sustained." 34 T.C. at 694. See also Kennedy v. United States, 109 F. Supp. 509 (D.R.I. 1952):

The defendant insists that the plaintiff cannot properly deduct the loss because he has not exhausted his legal remedies against those persons who were under suspicion. Such a requirement, however, places undue emphasis on form rather than substance. There is nothing in the record before the Court which would warrant the institution of either civil or criminal proceedings against any known person. . . The Court believes that plaintiff did all that could reasonably have been required of him under the circumstances.

Id. at 512 (emphasis added). See Treas. Reg. $\S 1.165-1$ (b) (1960), which provides that "substance and not mere form shall govern in determining a deductible loss." Furthermore, in Edwards, Monteleone and Kennedy, the taxpayer was granted the theft loss deduction. For a recent decision, see Skolnik v. Commissioner, 55 T.C. 1055 (1971).

124. Blue Chip Stamps v. Manor Drug Stores, 421 U.S. 723 (1975); Birnbaum v. Newport Steel Corp., 193 F.2d 461 (2d Cir.), cert. denied, 343 U.S. 956 (1952). See text accompanying notes 98-100 supra.

125. In other words, the defendant must have engaged in a proscribed activity under the rule. Basically, these fraudulent activities fall into two categories: a false or misleading statement and a failure to make a statement (omission). See 1 A. Bromberg \& 2.3(200). See also 37 AM. JUR. 2d Fraud § 4 (1968).

126. TSC Indus. v. Northway, Inc., 426 U.S. 438 (1976), though a proxy case, may be construed to define materiality for the purpose of Rule 10b-5. A fact is material "if there is a substantial likelihood that a reasonable shareholder would consider it important in deciding how to vote." Id. at 449 (emphasis added).

127. See text accompanying notes $153-60$ infra. 
Finally, the defendant must have possessed the requisite scienter in violation of the Rule. ${ }^{128}$ As will be seen below, proof of the first four elements satisfies the unlawful taking of property requirement of the theft loss deduction test and the scienter requirement directly corresponds to the criminal intent requirement.

The requirement that the shareholder be a purchaser or seller of securities was discussed earlier. ${ }^{129}$ The Supreme Court, in upholding that requirement for a 10b-5 cause of action, acknowledged its undesirability in that one need not have been a purchaser or seller in order to have suffered damages as aproximate result of a securities fraud. ${ }^{130}$ The Court's reasons for limiting the class of potential plaintiffs ${ }^{131}$ for purposes of federal securities law are unpersuasive as applied to tax law since the objective of the theft loss deduction is to provide the taxpayer with some tax relief for an actual loss. ${ }^{132}$ Thus, it is sufficient if the taxpayer merely held the security during the time period in which the value of the stock decreased as a result of the fraudulent activity.

The second and third requirements of a $10 \mathrm{~b}-5$ cause of action-that the defendant have employed a manipulative or deceptive device as to some material fact-correspond to the criminal law notion of a false representation which, in turn, corresponds to the tax law meaning of theft. As noted earlier, the tax law meaning of theft is very broad. Theft includes "swindling, false pretenses, and any other form of guile." 133 Consequently, the tax law meaning of "unlawful taking of property" is not nearly as limited or as technical as the meaning which the criminal law imports to that phrase. The criminal law meaning of "taking" arose specifically in reference to the crime of larceny. "The defendant does not commit larceny of another's property unless he 'takes' it in the sense of securing dominion over it."134 For purposes of tax law, a Treasury regulation provides that embezzlement is included

128. Erast \& Erast v. Hochfelder, 425 U.S. 185 (1976). See text accompanying note 161 infra.

129. See text accompanying notes $93-98$ supra.

130. See text accompanying note 96 supra. See also 1 A. Bromberg $\S 4.7(560)-(567)$. "The battle over the validity and desirability of the [purchaser-seller] requirement has been fierce and inconclusive." $J d$. \& 4.7(567).

131. See text accompanying note 95 supra.

132. 'The regulations in turn refer to losses 'actually sustained during the taxable period,' as fixed by 'identifiable events.' Such unmistakeable phraseology compels the conclusion that a loss, to be deductible under \& 23(e) [now I.R.C. \& 165(c)(3)], must have been sustained in fact during the taxable year." Boehm v. Commissioner, 326 U.S. 287, 292 (1945) (emphasis in original). The time for deducting a theft loss is the year of discovery. See text accompanying note 109 supra.

133. Edwards v. Bromberg, 232 F.2d 107, 110 (5th Cir. 1956).

134. W. LAFAve \& A. ScotT $\S 86$, at 631 . 
in the tax law meaning of theft. ${ }^{135}$ Yet, a "taking" is not an element of the criminal law definition of embezzlement. Instead, embezzlement is the fraudulent "conversion" of the property of another by one who is already in lawful possession of it. ${ }^{136}$ "A conversion of property requires a serious act of interference with the owner's rights." 137 Moreover, "[e]mbezzlement statutes often are worded in terms of the wrongdoer's conversion to his own use. These words are not to be taken literally, however, for it is not a requirement for a conversion that the converter gain a personal benefit from his dealing with the property." ${ }^{138}$ Lastly, the requisite mental state for the crime of embezzlement is the specific intent to defraud. ${ }^{139}$ Likewise, the tax court has permitted a theft loss deduction where the taxpayer has suffered loss as a result of a false pretense or fraud. ${ }^{140}$

The false pretense provisions of state law under which the theft loss deduction has been granted were statutory enactments of common law fraud, as is Rule 10b-5. In general, common law fraud ${ }^{141}$ is "knowingly and designedly obtaining the property of another by means of untrue representations of fact with intent to defraud." 142 The five general standing requirements of Rule 10b-5 closely parallel those of common law fraud. ${ }^{143} \mathrm{~A}$ major distinction between the two is that Rule $10 \mathrm{~b}-5$ includes relief for nondisclosure of material facts, whereas nondisclosure was rarely actionable under common law fraud. ${ }^{144}$ Otherwise there is no significant difference between the two, at least insofar as the victim is concerned. ${ }^{145}$ The distinctions between various theft

135. Treas. Reg. \& 1.165-8(d) (1960).

136. W. LAFAVE \& A. SCOTT $\& 89$, at 644 .

137. Id. \& 89, at 645 .

138. $I d$.

139. Id.

140. See Bellis v. Commissioner, 61 T.C. 354, 357 (1973), aff d, 540 F.2d 448 (9th Cir. 1976) (fraud included in the tax law meaning of theft); Evelyn Nell Norton, 40 T.C. 500 (1963), aff d, 333 F.2d 1005 (9th Cir. 1964); Michele Monteleone, 34 T.C. 688 (1960)).

141. The crime of false pretenses was created by a 1757 English statute which, although not enacted early enough to become technically a part of the common law in this country, has been generally accepted as a part of our common law. R. Perkins, Criminal Law 297 (2d ed. 1969).

142. Id.

143. See 1 A. BROMBERG § 2.7(1).

144. Id. "[T] he common law concept of fraud under the securities laws has now been enlarged under Rule 10b-5 to include even innocent nondisclosures which may amount to manipulative or deceptive conduct." Myzel v. Fields, 386 F.2d 718, 747 (8th Cir. 1967), cert denied, 390 U.S. 951 (1968).

145. Note, Federal Income Tax: The Dilemma of the Casualty Loss Deduction, 1961 DuKe L. J. 440. "From the taxpayer's standpoint there is no difference between loss by theft and loss due to misrepresentation." Id. 444 (citing R. PERKINS, supra note 141, at 319). See also Haimoff, Holmes Looks at Hochfelder and 10b-5, 32 Bus. LAw. 147, 148-49 (1976) (arguing that the scienter re- 
crimes serve no useful purpose either in the criminal law ${ }^{146}$ or in securities fraud cases.

The legislative expansion of common law fraud was necessary to provide adequate protection of property. ${ }^{147}$ The common law responded to the comparatively simple needs of the time. ${ }^{148}$ "Men had time to make their own investigations and usually did so, and it was not considered sound business or good common sense to rely on the mere oral statement of another." 149 In fact, the rationale for first imposing criminal sanctions on certain fraudulent conduct ${ }^{150}$ was that "the use of ordinary precaution and prudence would not be an adequate protection against [those] type[s] of fraud." ${ }^{151}$ Consequently, in light of the complex structure of the market system and the lack of opportunity of the shareholder to investigate statements by or about a corporation which are reported to the press, it became imperative that the law of criminal fraud expand into the area of the securities markets. ${ }^{152}$

A securities fraud under Rule 10b-5 is the counterpart of common law fraud in the context of the marketing of securities. Given the inclusion of fraud in the tax law definition of theft, and given that a securities fraud closely approximates a crime which is already included in the tax law meaning of theft, it is reasonable to conclude that a securities fraud should fall within that sphere of crimes to which the theft loss deduction applies.

The fourth general standing requirement for a Rule 10b-5 cause of action is that the plaintiff's reliance on such deception must have

quirement, as defined in Hochfelder, is the equivalent of the mental state requirement of common law fraud).

146. R. PERKINS, supra note 141 , at 319.

147. Id. 232.

148. Id. 231.

149. Id.

150. Originally, there was no criminal penalty for taking property under false pretenses except where false tokens were used. $I d$.

151. Id. Although only personal movable things could be the objects of the crime under the common law, statutes have expanded the application of the crime to acts such as fraudulent advertisement, unauthorized wearing of a badge or garb of a secret society with intent to deceive, obtaining food or lodging at a hotel with intent to defraud and circulation of false rumors as to stocks and bonds with intent to affect the market price. Id. 297-98.

152. SEC v. Capital Gains Research Bureau, Inc., 375 U.S. 180 (1963). Although this case concerned the Investment Advisors Act of 1940, the Supreme Court, in reference to practices proscribed under the securities laws which operate as a fraud or deceit, stated that "the courts have adapted the common law of fraud to the commercial transactions of our society." Id. at 192. In fact, one treatise suggests that it was the securities markets which helped develop common law fraud. "The common law of deceit, in fact, has developed to some extent in the context of fraud in the sale of securities." H. Bloomenthal \& S. WING, Securities Law \& 8.07, at 8-72 (1973) (citing Derry v. Peek, 14 App. Cas. 337, 55 L.J. Ch. 864 (1889)). See also Haimoff, supra note 145, at 163. 
caused the damage. As noted earlier, ${ }^{153}$ the IRS has denied a theft loss deduction to a defrauded investor where the investor purchased his shares on the open market and consequently was not in privity with the malefactors. Perhaps this holding is correct as applied to state law, which was the law under which the taxpayer had alleged that a theft had occurred. However, "privity between plaintiffs and defendants is not a requisite element of a Rule 10b-5 cause of action for damages."154 "In short, causation as an element of a Rule 10b-5 cause of action can be established notwithstanding lack of privity."15s

According to Professor Bromberg, causation can be broken down into two elements: the violation must have caused the loss and the violation must have caused the transaction. ${ }^{156}$ For loss causation to exist the shareholder must be able to show direct economic harm. ${ }^{157}$ Such loss is reflected in the decrease in the value of the stock. Transaction causation requires that the plaintiff relied on the deception upon entering the transaction. ${ }^{158}$ In cases of nondisclosure of material facts, transaction causation is easily proven as a result of the Supreme Court's holding in Affiliated Ute Citizens v. United States ${ }^{159}$ that in such cases reliance will be assumed. In cases of misstatements of material fact, the plaintiff must show that the alleged fraud induced his purchase or sale. ${ }^{160}$

However, a shareholder does not have standing to sue unless he alleges that the wrongdoer possessed the appropriate scienter. Likewise, the second part of the theft loss deduction test is that the taxpayer must allege that the illegal act was accompanied by criminal intent. Generally, crime requires a specific state of mind which is variously called

153. See text accompanying notes 33-39 supra.

154. Shapiro v. Merrill Lynch, Pierce, Fenner \& Smith, Inc., 495 F.2d 228, 239 (2d Cir. 1974). But cf. Fridrich v. Bradford, 542 F.2d 307 (6th Cir. 1976), cert. denied, 429 U.S. 1053 (1977) (where insider trading had no effect on market price or plaintiffs portfolio decisions, defendants are not liable to traders on the open market).

155. Shapiro v. Merrill Lynch, Pierce, Fenner \& Smith, Inc., 495 F.2d 228, 239 (2d Cir. 1974). See also Mitchell v. Texas Gulf Sulphur Co., 446 F.2d 90 (10th Cir.), cert. denied, 404 U.S. 1004 (1971), where the Tenth Circuit stated that "the first step is to realize that the common law requirement of privity has all but vanished from $10 \mathrm{~b}-5$ proceedings while the distinguishable 'connection' element is retained." 446 F.2d at 101.

156. 2 A. Bromberg $\$ 4.7(551)$. See also Note, Causation and Liability in Private Actions for Proxy Violations, 80 YALE L.J. 107, 123-24 (1970).

157. See Schlick v. Penn-Dixie Cement Corp., 507 F.2d 374 (2d Cir. 1974) (there must be direct economic harm).

158. "This kind of causation . . . tests whether the violation caused the transaction in question . . . . Causation in such a situation contemplates that plaintiff is the decision maker in the transaction, and that his compensable loss flows from the distortion of his decisional process by the violation." 2 A. BROMBERG $§ 4.7(551)(2)$.

159. 406 U.S. 128 (1972).

160. See 1 A. BromberG 4.7(551)(2), at 86.6 . 
mens rea, scienter or criminal intent. ${ }^{161}$

For purposes of tax law, a showing of criminal intent requires evidence of guilty knowledge or intent. ${ }^{162}$ Because of the considerable inconsistency in terminology encountered when making comparisons of different bodies of law, ${ }^{163}$ this Comment will use the Model Penal Code definitions. ${ }^{164}$ Accordingly, the four kinds of mental states, in order of increasing culpability, are: (1) negligence, ${ }^{165}$ (2) recklessness (which includes gross negligence), ${ }^{166}(3)$ knowledge $^{167}$ and (4) purposefulness ${ }^{168}$ (which has the same meaning as intent ${ }^{169}$ and design ${ }^{170}$ ).

In Ernst \& Ernst v. Hochfelder, ${ }^{171}$ the Supreme Court stated in dictum that an action for damages under section 10(b) and Rule 10b-5 will not lie in the absence of an allegation of an intent to deceive, ma-

161. See W. LAFAve \& A. ScotT \& 27, at 192. 1976).

162. See Bellis v. Commissioner, 61 T.C. 354,357 (1973), affd, 540 F.2d 448 (9th Cir.

163. See W. LaFave \& A. ScotT $\$ 27$, at 192-95.

164. Model Penal Code $\S 2.02(2)$ (Proposed Official Draft 1962).

165. Negligently.

A person acts negligently with respect to a material element of an offense when he should be aware of a substantial and unjustifiable risk that the material element exists or will result from his conduct. The risk must be of such a nature and degree that the actor's failure to perceive it, considering the nature and purpose of his conduct and the circumstances known to him, involves a gross deviation from the standard of care that a reasonable person would observe in the actor's situation.

Id. $\$ 2.02(2)(\mathrm{d})$.

166. Recklessly.

A person acts recklessly with respect to a material element of an offense when he consciously disregards a substantial and unjustifiable risk that the material element exists or will result from his conduct. The risk must be of such a nature and degree that, considering the nature and purpose of the actor's conduct and the circumstances known to him, its disregard involves a gross deviation from the standard of conduct that a lawabiding person would observe in the actor's situation.

Id. $\$ 2.02(2)(c)$ (emphasis added).

167. Knowingly.

A person acts knowingly with respect to a material element of an offense when:

(i) if the element involves the nature of his conduct or the attendant circumstances, he is aware that his conduct is of that nature or that such circumstances exist; and

(ii) if the element involves a result of his conduct, he is aware that it is practically certain that his conduct will cause such a result.

Id. $\$ 2.02(2)(\mathrm{b})$.

168. Purposely.

A person acts purposely with respect to a material element of an offense when:

(i) if the element involves the nature of his conduct or a result thereof, it is his conscious object to engage in conduct of that nature or to cause such a result; and

(ii) if the element involves the attendant circumstances, he is aware of the existence of such circumstances or he believes or hopes that they exist.

Id. $\$ 2.02(2)$.

169. " 'II]ntentionally' or "with intent' means purposely." Id. § 1.13(12).

170. "'P]urposely' has the same meaning specified in Section 2.02 and equivalent terms such as 'with purpose,' 'designed' or 'with design' have the same meaning." Id. $\S 1.13(11)$.

171. 425 U.S. 185 (1976). 
nipulate or defraud. ${ }^{172}$ Clearly, Hochfelder eliminates the first mental state-negligence-as a basis on which to bring a private 10b-5 action. ${ }^{173}$ However, there is considerable debate as to whether an allegation of recklessness is sufficient to satisfy the scienter requirement of Rule 10b-5. ${ }^{174}$ In Hochfelder, the Supreme Court stated: "We need not address here the question whether, in some circumstances, reckless behavior is sufficient for civil liability under $\S 10$ (b) and Rule 10b-5."175 On the other hand, the reckless behavior to which the Supreme Court referred was recklessness which is considered to be a form of intentional conduct. ${ }^{176}$ Thus, recklessness, as defined by the Model Penal Code, will not satisfy the scienter requirement since knowing or intentional conduct is not included in the Code definition of recklessness. ${ }^{177}$

Although it was not so held in Hochfelder, the Supreme Court used the phrase "knowing or intentional conduct" in reference to the mental state which satisfied the scienter requirement for private $10 \mathrm{~b}-5$ actions. ${ }^{178}$ Likewise, the tax court in Bellis, defined criminal intent as "guilty knowledge or intent"179 and in a 1971 revenue ruling the IRS

172. Id. at 193.

173. "The judicially created private damage remedy under $\$ 10(\mathrm{~b})$. . . cannot be extended, consistently with the intent of Congress, to actions premised on negligent wrongdoing." Id. at 210.

174. See, e.g., Pitt, U.S. Supreme Court Must Resolve Uncertainties Caused by Hochfelder, N.Y.L.J., Dec. 19, 1977, at 30, col. 1, 55, col. 2. The following cases have allowed recovery for reckless conduct: Wright v. Heizer Corp., 560 F.2d 236 (7th Cir. 1977); Sanders v. John Nuveen Co. Inc., 554 F.2d 790 (7th Cir. 1977); Sunstrand Corp. v. Sun Chemical Corp., 553 F.2d 1033 (7th Cir. 1977); Herzfeld v. Laventhol, Krekstein, Horwath and Horwath, 540 F.2d 27 (2d Cir. 1976); Bailey v. Meister Brau, Inc., 535 F.2d 982 (7th Cir. 1976).

175. 425 U.S. at 194 n.12.

176. "In certain areas of the law recklessness is considered to be a form of intentional conduct for purposes of imposing liability for some act." Id. (emphasis added). See SEC v. Bausch \& Lomb, Inc., 420 F. Supp. 1226, 1243 n.4 (S.D.N.Y. 1976), affd on other grounds, 565 F.2d 8 (2d Cir. 1977) (Hochfelder scienter requirement "leads to the conclusion that only . . . "the kind of recklessness that is equivalent to wilfull fraud' . . . serves as a basis of liability"). See also Bailey v. Meister Brau, Inc., 535 F.2d 982 (7th Cir. 1976) (corporation liable for reckless conduct under 10b-5 where "blinded by conflict of interest" it "wantonly ignored" readily available evidence of the unfaimess of a proposed acquisition).

177. See note 166 supra. The Model Penal Code definition of recklessness describes that mental state as a conscious disregard of a risk. MODEL Penal CODE \$ 2.02(s)(c) (Proposed Official Draft 1962). A risk is defined as a "chance of injury." WEBSTER's NEw WORLD DictionARY 1228 (2d ed. 1972). However, recklessness under the Model Penal Code does not require that the actor be "practically certain that his conduct will cause such a result," which is one of the requirements for acting knowingly. See note 167 supra. Thus, it is reasonable to conclude that for recklessness to be a form of intentional conduct there must be a conscious disregard for a chance of injury and that chance must be so great that the actor is practically certain that his conduct will cause such an injury. The distinction is one of degree of probability. See Haimoff, supra note 145, at 149-50 (discussion of Holmes' general theory of tort law and the application of that theory to fraud).

178. 425 U.S. at 197.

179. "Without evidence of guilty knowledge or intent on Jansen's part petitioner does not reach the threshold point of our broad definition of theft." 61 T.C at 357. 
granted a theft loss deduction, finding that the wrongdoer acted "knowingly, with intent to defraud." ${ }^{180}$ Thus, a strong argument can be made that the criminal intent standard in the theft loss deduction test is the equivalent of the scienter requirement in private $10 \mathrm{~b}-5$ actions.

At this point it is important to reiterate that the taxpayer who is seeking the theft loss deduction is required to prove only that the loss was "occasioned by circumstances clearly indicating theft." 181 Suppose, for example, that a taxpayer who has owned shares in a corporation for several years notices a sudden and dramatic decrease in the value of his stock. This event in itself is not a circumstance clearly indicating theft. However, if, after noticing such a decrease, the taxpayer learns (either actually or constructively) that other shareholders are seeking private damages under Rule 10b-5 and have standing to sue under Rule 10b-5, then an identifiable event occurs enabling the taxpayer to "officially" discover his loss. Assuming that the party instituting suit has presented a colorable claim, not only does the identifiable event fix the year of discovery for the taxpayer, but it also serves as proof that the taxpayer's loss was the result of a theft. The taxpayer himself need not have standing to sue in order to claim damage as a result of a securities fraud. "For $\S 10(\mathrm{~b})$ bans the use of any deceptive device in the 'sale' of any security by "any person." "182 The Supreme Court recognized in Blue Chip that one may not have standing to sue under Rule $10 \mathrm{~b}-5$ and yet may still be damaged as a proximate result of a $10 \mathrm{~b}-5$ violation since a decline in the value of stock affects all stockholders. ${ }^{183}$ Thus, all the taxpayer need allege to provide the I.R.S. with an identifiable event is that he was a holder of the security during the decrease in value, that there is someone who has standing to bring a private $10 \mathrm{~b}-5$ action and that the suit against the corporate malefactors presents a colorable claim.

2. SEC Enforcement Proceedings as Identifying Events. SEC enforcement proceedings may also function as timing or identifying

For a recent decision interpreting the criminal intent element see James Godine, Jr., 36 T.C.M. 1595 (CCH) I 34,739, at 1598 (1977) (theft loss deduction denied because petitioner failed to prove that defendant "knowingly and designedly" made false statements) (citing Norton v. Commissioner, 333 F.2d 1005 (9th Cir. 1964)).

Regarding the combination of knowledge and/or intent it should be noted that "[t]he word 'intent' in the substantive criminal law has generally not been limited to the narrow, dictionary definition of purpose, aim, or design, but that it has often been viewed as encompassing much of what would ordinarily be described as knowledge." MODEL PENAL CODE $§ 2.02$, Comment (Tent. Draft No. 4, 1955).

180. Rev. Rul. 381, 1971-2 C.B. 126.

181. See text accompanying note 123 supra.

182. Superintendent of Ins. v. Bankers Life \& Cas. Co., 404 U.S. 6, 8 (1971) (emphasis added).

183. See text accompanying note 96 supra. 
events. Section 32 of the 1934 Act imposes criminal sanctions for violations of the Act or the rules and regulations promulgated under it. ${ }^{184}$ During fiscal year 1976, the SEC referred 116 cases to the Department of Justice for criminal prosecution, of which 97 resulted in convictions. ${ }^{185}$ The statutory provision defining a criminal violation requires "willfulness," 186 rendering the quality and quantity of evidence needed to maintain a criminal action at least as great as that required for a private 10b-5 action. Clearly, the elements of a private $10 \mathrm{~b}-5$ action and a criminal action are very similar. ${ }^{187}$

Probable cause must exist before the Justice Department can proceed to prosecute the alleged perpetrators of the fraud. Yet, the taxpayêr is required to show only that there are circumstances which clearly indicate theft. ${ }^{188}$ In Monteleone, the tax court granted a theft loss deduction despite the fact that criminal proceedings brought against the alleged swindler were terminated with the dismissal of both the indictment and the information for lack of probable cause. ${ }^{189}$

184. See text accompanying note 88 supra.

185. Securities and Exchange Commission, 42D ANnual Report of the SEC, H.R. Doc. No. 21, 95th Cong., Ist Sess. 206-07 (1977):

CRIMINAL CASES

\begin{tabular}{|c|c|c|c|c|}
\hline Fiscal Year & $\begin{array}{l}\text { Number of } \\
\text { cases } \\
\text { referred to } \\
\text { Justice } \\
\text { Department }\end{array}$ & $\begin{array}{l}\text { Number of } \\
\text { Indictments }\end{array}$ & $\begin{array}{c}\text { Defendants } \\
\text { Indicted } \\
\end{array}$ & Convictions \\
\hline 1967 & 44 & 53 & 213 & 127 \\
\hline 1968 & 40 & 42 & 123 & 84 \\
\hline 1969 & 37 & 64 & 213 & 83 \\
\hline 1970 & 35 & 36 & 102 & 55 \\
\hline 1971 & 22 & 16 & 83 & 89 \\
\hline 1972 & 38 & 28 & 67 & 75 \\
\hline 1973 & 49 & 40 & 178 & 83 \\
\hline 1974 & 67 & 40 & 169 & 81 \\
\hline 1975 & 88 & 53 & 199 & 116 \\
\hline 1976 & 116 & 23 & 118 & 97 \\
\hline
\end{tabular}

186. 15 U.S.C. $\$ 78 f$ (1976). The imprisonment sanction will not be imposed if the violator can establish that he had no knowledge of the statute. Id. However, this defense has not been prevalent. See 4 A. BROMBERG $\S 10.3$.

187. "[P]recedents established in civil cases interpreting Rule 10b-5 are applicable in criminal prosecutions under the Rule . . . United States v. Chanay, 537 F.2d 341, 348 (9th Cir.), cert. denied, 429 U.S. 1000 (1976). The circuit court in Charnay concluded that manipulation meant the same in criminal $10 \mathrm{~b}-5$ cases as in civil $10 \mathrm{~b}-5$ cases. 537 F.2d at 348-51. Under the Model Penal Code definitions of the various types of mental states, willfulness is equivalent to intentional conduct. See notes 167-68 supra.

188. See text accompanying note 123 supra.

189. 34 T.C. at $693-94$. 
Therefore, the institution of a criminal proceeding, insofar as it requires probable cause, is a circumstance which indicates the likelihood that a theft has occurred. Of course, the stockholder who uses the criminal proceeding as an identifiable event still must be able to show causation, that is, that his loss was a proximate result of the unlawful activity. This is a question of fact to be resolved on the basis of the substantiality of the loss involved and the temporal relationship between taxpayer's ownership of stock, the time at which the SEC alleged that the fraud occurred, and the institution of the SEC proceeding.

Other possible identifying events are SEC proceedings triggered by alleged $10 \mathrm{~b}-5$ violations. The Commission has the discretion to decide whether or not to commence proceedings. ${ }^{190}$ Where $10 \mathrm{~b}-5$ is concerned, an SEC enforcement proceeding can be commenced whenever a material misrepresentation, misleading omission or other deception or manipulation ${ }^{191}$ occurs in connection with a purchase or sale of a security. ${ }^{192}$ The enforcement measures available to the SEC to combat such violations include suspension of trading, ${ }^{193}$ injunctions and suspension of registration with the Commission. ${ }^{194}$ For example, in order for the SEC to obtain a preliminary injunction, it must present prima facie evidence that an individual's conduct constitutes a violation of the antifraud provisions and that the individual's conduct indicates a rea-

190. See, e.g., SEC v. Aldred Investment Trust, [1961-1964 Transfer Binder] FeD. SEC. L REP. (CCH) ๆ 91,349 (D.C.N.Y., Dec. 24, 1963).

191. 1 A. BRomberg $\S 10.1$ (citing SEC v. Texas Gulf Sulpher Co., 258 F. Supp. 262, 277-78 (S.D.N.Y 1966), modified, 401 F.2d 833 (2d Cir. 1968), cert. denied, 394 U.S. 976 (1969)).

192. It is not necessary that the SEC be a purchaser or seller to pursue enforcement proceedings. Cf. Mutual Shares Corp. v. Genesco, Inc., 384 F.2d 540 (2d Cir. 1967) (buyer-seller requirement waived in shareholder injunction suits).

193. See note 3 supra. Between February 11, 1959 and June 30, 1977, the SEC suspended trading in approximately 933 issues. Memorandum from SEC Division of Enforcement, Branch of Market Surveillance (July 7, 1977) (on file with the Duke Law Journal). Although activities other than fraudulent conduct often precipitate trading suspensions, the suspension period is generally longer when fraudulent conduct is suspected. For example, in Continental Vending Machine Corp., trading was suspended from March 8, 1963 to June 2, 1976; in Equity Funding Corp. of America, the suspension period was from March 28, 1973 to October 17, 1976; and in Home-Stake Production Co., trading was suspended from August 8, 1973 to May 17, 1974. Id.

Although the incidence of securities fraud may appear quantitatively small, it must be remembered that a $10 \mathrm{~b}-5$ violation which causes a decline in the value of even one corporation could affect thousands of shareholders. For example, one Fortune 500 corporation, the DuPont Company, reports that its $48,291,708$ shares of outstanding common stock are owned by 204,665 individual shareholders. [1976] E.I. DuPont De Nemours \& Co., ANnual Report 1. Presumably, the majority of individual shareholders are also individual taxpayers and not corporations or partnerships. See note 23 supra. In 1975, there were 18,112,000 individual shareholders with annual incomes under $\$ 25,000$. U.S. Bureau of the Census, Statistical AbStract of the United States: 1976 at 497 (97th ed.) (citing New York Stock Exchange, InC., Census of SHAREOWNERS (1975)):

194. See note 4 supra. 
sonable likelihood of future violations. ${ }^{195}$ Such a standard parallels the tax law requirement that a taxpayer's loss be occasioned by circumstances clearly indicating theft. ${ }^{196}$

Since an SEC proceeding has been defined as any action taken by the SEC directed by a formal order, ${ }^{197}$ such SEC activities as no-action letters should not be used as identifiable events for tax purposes. ${ }^{198}$ Identifiable events should consist only of those proceedings as to which the Commission has issued a final order since only final orders are reviewable in the courts. ${ }^{199}$ Upon review, SEC findings of fact are conclusive if supported by substantial evidence. ${ }^{200}$

As with SEC referrals to the Department of Justice for criminal proceedings, the taxpayer must still be able to show causation. ${ }^{201}$ Again, this will require proof of issues of fact.

Unfortunately, the use of the SEC proceeding as an identifiable event presents some problems. For SEC enforcement proceedings to serve as identifiable events, the SEC must allege knowing or intentional conduct, the same mental state a taxpayer must allege in order to successfully deduct his loss as a "theft." Yet, there is considerable uncertainty as to whether the Hochfelder scienter requirement is applicable to the Commission in its various enforcement proceedings, ${ }^{202}$ despite the fact that the Supreme Court spoke in terms of the language of section 10(b), not in terms of the language of section 10(b) as applied only to private actions. ${ }^{203}$ Several district courts have held or indicated in 1973).

195. See, e.g., SEC v. Charles A. Morris \& Assoc., Inc., 386 F. Supp. 1327 (W.D. Tenn.

196. See text accompanying note 123 supra.

197. United States v. Batten, 226 F. Supp. 492 (D.D.C.), affd without op., (D.C. Cir. Oct. 15, 1964), cert. denied, 380 U.S. 912 (1965).

198. No-action letters are letters in which members of the SEC staff advise the person soliciting its views that, under a described set of facts, the staff would not recommend that the Commission take any action. [1972] 1 FED. SEC. L. REP. (CCH) I 134. They are available to the public 30 days after the response is sent. The SEC is not bound by the informal expression of opinion contained therein. Id.

199. See Kixmiller v. SEC, 492 F.2d 641 (D.C. Cir. 1974) (a no-action letter is not a Commission order).

200. See Wright v. SEC, 112 F.2d 89 (2d Cir. 1940).

201. See text accompanying notes $156-57$ supra (the violation must have caused the loss).

202. See Pith, supra note 174, at 55, col. 2.

203. For example, the Court stated that "[t]he words 'manipulative or deceptive' used in conjunction with 'device or contrivance' strongly suggest that $\S 10(\mathrm{~b})$ was intended to proscribe knowing or intentional conduct." Hochfelder, 425 U.S. at 197. In short, the Court looked to the common meaning of manipulation and deception and concluded that intentional wrongdoing was that common meaning. Id. at 214.

Actually, the conclusion that one scienter standard applies to all proceedings brought under section 10(b) would be consistent with the Supreme Court's earlier view, as articulated in SEC v. Capital Gains Research Bureau, Inc., 375 U.S. 180 (1963), that section 10(b) is the counterpart to 
dicta that Hochfelder applies to any proceeding brought under 10b-5, whether by private shareholders or by the Commission. ${ }^{204}$ Likewise, Professor Bromberg has commented that "[i]t should not be substantively easier for the SEC to achieve this [private relief] than for injured individuals." ${ }^{205}$ The Court of Appeals for the First Circuit, however, has held that the Hochfelder scienter requirement does not apply to the Commission in its own injunctive proceedings. ${ }^{206}$

In view of the uncertainty in this area, the SEC may continue to institute proceedings based on allegations of recklessness, common-law fraud or even negligent misconduct. ${ }^{207}$ Thus, the validity of the SEC proceeding as an identifiable event indicating the likelihood of tax law theft is debatable unless the SEC clearly asserts in the market release that knowing or intentional misconduct has occurred.

In summary, the private action, SEC referrals to the Justice Department for criminal proceedings and perhaps SEC enforcement proceedings are all identifiable events which could be used by the taxpayer not only to pinpoint the year of discovery, but also to serve as a circumstance clearly indicating that a theft has occurred within the meaning of theft under tax law.

\section{A Reasonable Prospect of Recovery and the TaX-Benefit RULE}

A theft loss is not deductible under section 165 if there is a reasonable prospect of recovery. ${ }^{208}$ Whether a reasonable prospect of recovery exists is a question of fact to be resolved upon an examination

common law fraud in the context of the securities markets. See text accompanying notes 141-152 supra. In Bentel v. United States, 13 F.2d 327 (2d Cir. 1926), which concerned the sale of stock on false prospectuses, the Second Circuit noted that, as far as the common law was concerned, the same rules of fraud applied in criminal as in civil cases, and that "only the necessary quantum of probative force changes." Id. at 329. See Haimoff, supra note 145, at 157-58. See also United States v. Simon, 425 F.2d 796, 808 (2d Cir. 1969), cert. denied, 397 U.S. 1006 (1970). Since the mental state requirement in common law fraud is the same in criminal as in civil cases, it would be consistent with common law fraud to require the same mental state within the various civil proceedings whether brought by private litigants or the SEC.

204. See SEC v. Cenco, Inc., 436 F. Supp. 193 (N.D. Ill. 1977) (Hochfelder fully applicable to SEC injunction proceedings); SEC v. American Realty Trust, 429 F. Supp. 1148 (E.D. Va. 1977), appeal pending, No. 77-1839 (4th $\mathrm{Cir}$ ) (Hochfelder applies to SEC injunctive proceedings); SEC v. Bausch \& Lomb, Inc., 420 F. Supp. 1226, 1243 n.4 (S.D.N.Y. 1976), aff'd on other grounds, 565 F.2d 8 (2d Cir. 1977) (in dictum court indicated Hochfelder should be fully applicable to SEC enforcement proceedings).

205. 4 A. BROMBERG § 10.1.

206. SEC v. World Radio Mission, Inc., 544 F.2d 535 (1st Cir. 1976).

207. See generally Pitt, supra note 174 , at 55 , col. 2; see also Note, supra note 98 , at 327 n.14, 352 .

208. Treas. Reg. $\S 1.165-8(a)(2)(1960)$. 
of all the facts and circumstances. ${ }^{209}$ In Ramsay Scarlett \& Co. $v$. Commissioner, ${ }^{210}$ the tax court stated that a "reasonable prospect of recovery exists when the taxpayer has bona fide claims for recoupment from third parties or otherwise, and when there is a substantial possibility that such claims will be decided in his favor."211 This standard is to be applied by foresight such that only those facts reasonably foreseeable as of the close of the taxable year are considered. ${ }^{212}$ If a taxpayer determines, as of the last day of the taxable year in which the theft was discovered, that he has a reasonable prospect of recovering all or some part of the loss, then he must postpone the deduction until he can be reasonably certain such reimbursement will not be received. ${ }^{213}$

The reasonable prospect of recovery rule is a corollary to the general tax law rule that losses must be evidenced by "closed and completed transactions."214 There is, however, an exception to the completed transaction rule for worthless securities. ${ }^{215}$ The worthless securities deduction permits the taxpayer to treat a decline in the value of stock as a capital loss arising from the sale or exchange of a capital asset so long as worthlessness can be established. ${ }^{216}$ The test of worthlessness is whether a "prudent businessman would have ascertained the stock to be worthless." 217 In comparison, in the reasonable prospect of recovery test, whether there is a reasonable prospect of recovery is a question of fact to be resolved upon examination of all the facts and circumstances. ${ }^{218}$ Neither the theft loss provision nor the worthless securities provision require the taxpayer to pursue measures to recoup the loss. ${ }^{219}$ However, the worthlessness test and the reasonable prospect of recovery test do not require the same burden of proof and it was upon this point that the IRS erred in Revenue Ruling 77-18. ${ }^{220}$

209. Treas. Reg. $\$ 1.165-1(d)(2)(i)$ (1960).

210. 61 T.C. 795 (1974).

211. Id. at 811-12 (citing Estate of Scofield v. Commissioner, 266 F.2d 154, 159 (6th Cir. 1959)). See also Foundation Co., 14 T.C. 1333, 1351, 1354 (1950). Also see Boehm v. Commissioner, 326 U.S. 287 (1945), where the Supreme Court upheld a tax court case which found that a taxpayer had no reasonable prospect of recovery since there was no "substantial value to the suit." Id. at 294.

212. 61 T.C. at 811.

213. Treas. Reg. $§ 1.165-1(d)(2)(i)(1960)$.

214. Treas. Reg. \& 1.165-1(d)(1) (1960).

215. I.R.C. $\$ 165(\mathrm{~g})$. See note 20 supra and accompanying text.

216. I.R.C. $\& 165(\mathrm{~g})(1)$.

217. 5 J. MERTENS, supra note $115, \S 28.65$, at 291.

218. Id.

219. Regarding the theft loss deduction, see text accompanying note 141 supra. Regarding the worthless securities deduction, see J. CHOMmIE, supra note $21, \S 61$.

220. 1977-1 C.B. 46. See text accompanying notes 40-43 supra. See also Rev. Rul. 381, 197134 I.R.B. 12 (taxpayer was entitled to theft loss when loans became worthless). 
The worthlessness test requires the taxpayer to prove that "[t]he last vestige of value has disappeared" from the stock. ${ }^{21}$ Such an onerous burden is generally carried when a corporation is dissolved or liquidated; however, dissolution or liquidation is not required. ${ }^{222}$ This burden is so heavy that one commentator has stated that "[t]he right to the deduction may often be chimerical unless this difficulty is honestly recognized."223

On the other hand, the reasonable prospect of recovery test requires the taxpayer to prove by a preponderance of the evidence ${ }^{224}$ either that he has no bona fide claims for recoupment or that there is no substantial possibility that his bona fide claims will be decided in his favor. ${ }^{225}$ This formulation was the result of a rebuttable presumption, articulated in Estate of Scofield $v$. Commissioner, ${ }^{226}$ that "where a taxpayer is in good faith willing to go to the trouble and expense of instituting suit ... there is as a matter of fact sufficient chance of at least part of recovery to justify that the taxpayer defer the claim . . . until the litigation in question is concluded."227 Since the taxpayer's subjective opinion as to the success of litigation is not controlling ${ }^{228}$ and, in fact, may carry little probative force under the facts and circumstances of any given case, ${ }^{229}$ the above test should be viewed as an objective one. ${ }^{230}$ Thus, a reformulation of the presumption is that if any part of a class of taxpayers who have suffered a loss due to theft brings suit to recover damages, then a reasonable prospect of recovery exists.

Clearly, there is a considerable difference in the burden of proof between the two tests. In the worthlessness test the burden is to show that no value exists in the stock whatsoever. If the reasonable prospect of recovery test were meant to be as burdensome as the worthlessness test, the theft loss deduction would be denied whenever a mere possibility of recovery existed. On the contrary, the applicable standard for the reasonable prospect of recovery test is whether there is a $s u b$ -

221. Bodzy v. Commissioner, 321 F.2d 331, 335 (5th Cir. 1963) (quoting Miami Beach Bay Shore Co. v. Commissioner, 136 F.2d 408 (5th Cir. 1943)).

222. 5 J. MERTENS, supra note $115, \S 28.65$, at 291.

223. Id. § 28.65, at 292.

224. Spiegel v. United States, $75-2$ U.S. Tax Cas. (CCH) \ 9667, at 88,206 (S.D. Fla. 1975) (conclusion of law \# 4). See also Hudock v. Commissioner, 65 T.C. 351, 361 (1975).

225. See authority cited in note 195 supra.

226. 266 F.2d 154 (6th Cir. 1959).

227. Id. at 159.

228. See United States v. White Dental Co., 274 U.S. 398, 403 (1927).

229. See Ramsay Scarlett \& Co. v. Commissioner, 61 T.C. 795, 812-13 (1974).

230. See Parmelee Transp. Co. v. United States, 315 F.2d 619, 628 (Ct. Cl. 1965); Estate of Scofield v. Commissioner, 266 F.2d 154, 163 (6th Cir. 1959). 
stantial possibility that bona fide claims will be decided in taxpayer's favor.

Assuming the small investor has overcome the numerous obstacles to bringing a class action for damages, ${ }^{231}$ then the rebuttable presumption contained within the reasonable prospect of recovery test results in an inference that all members of that class action have a reasonable prospect of recovery. However, such a presumption can be rebutted, albeit with difficulty, by an individual investor if that investor opts out of the class and otherwise presents objective facts evidencing the unlikelihood of recovery. ${ }^{232}$ Moreover, the presumption articulated in Scofield did not arise in the context of class actions. ${ }^{233}$ Thus, the relevance of such a test to a defrauded shareholder is debatable since most members of the class do not go to any trouble or expense to institute suit. Nonetheless, the fact that there were common victims of the alleged theft who thought the suit worth pursuing lends support to the application or modified application of this rebuttable presumption.

In Revenue Ruling 77-18, ${ }^{234}$ the IRS held that bankruptcy reorganization or recission of a merger tainted by fraud could serve as a recovery. ${ }^{235}$ Such a holding is not a fair application of the reasonable prospect of recovery test as applied to shareholders. A bankruptcy reorganization is subject to the "absolute priority" rule which means that

[e]ach class of creditors and shareholders, beginning with the most senior, highest priority claim, must receive under the plan securities or other consideration fully equal in value to their preexisting interests before the next junior class may receive anything, thus, shareholders may receive nothing in a corporation insolvent in the bankruptcy sense; common shareholders may only participate after preferred shareholders have received the full equivalent of their liquidation preferences. ${ }^{236}$

231. See text accompanying notes 11-16 supra.

232. See, e.g., Boehm v. Commissioner, 326 U.S. 287 (1945). "The mere fact that defendants were financially responsible does not necessarily inject any recognizable value into the suit from the stockholders' viewpoint. Hence it was reasonable to conclude that all value had departed from the stock prior to 1937 and that there was nothing left except a claim for damages against third parties for destruction of that value." Id. at 294-95. See also Ramsay Scarlett \& Co. v. Commissioner, 61 T.C. 795 (1974). "Nor does the fact of a future settlement of favorable judicial action on the claim control our determination, if we find as of the close of the particular year, no reasonable prospect of recovery existed." Id. at 811-12.

233. Estate of Scofield v. Commissioner, 266 F.2d 154, 159 (6th Cir. 1959). Scofield involved a successor-trustee of a testamentary trust who brought suit against the original trustee for breach of trust and diversions of trust assets.

234. 1977-1 C.B. 46. See text accompanying notes 40-43 supra.

235. 1977-1 C.B. at 47.

236. H. HENN, supra note $12, \S 388$, at 833 . 
Given that common shareholders are the last to be compensated by a corporation which is in the situation of either having an excess of liabilities over assets or being unable to pay debts as they mature, ${ }^{237}$ the possibility of recovery for such shareholders is clearly not substantial. Likewise, rescission of a merger is an unlikely remedy. Because "[r]escission calls for cancellation of the bargain, and the return of the parties to the status quo ante"238 it is rarely a remedy either sought by the plaintiff or awarded by the court. ${ }^{239}$ Whenever suit is brought long after the transaction in question ${ }^{240}$ or whenever the current market price is below the tender offer price, ${ }^{241}$ then rescission is an inappropriate remedy. Thus, it is the fluctuating nature of the stock market itself that renders rescission an unlikely remedy. ${ }^{242}$

Another reason why the courts should be liberal in their application of the reasonable prospect of recovery test to the securities fraud situation is the tax benefit rule. The tax benefit rule provides that if a taxpayer took a deduction for which he received a tax benefit only to recover part or all of the loss in a subsequent year, then the recovery in the subsequent year will be recognized as gross income. ${ }^{243}$ The determination of when a loss is to be deducted calls for a practical test. ${ }^{244}$ The average investor in the securities markets is "at a serious disadvantage in dealing with persons possessing superior knowledge, skill and resources." 245 This disadvantage also exists regarding the taxpayer's abil-

237. "While insolvency of the bankrupt is not essential under bankruptcy law, it usually exists and is a relevant factor for various purposes of the law." Id. $\$ 383$, at 821 . Insolvency in the bankruptcy sense exists when a corporation has an excess of liabilities over assets, at fair market value. Insolvency in the equity sense exists when a corporation demonstrates an inability to pay debts as they mature. Id. $\$ 383$, at $821 \mathrm{n} .8$.

238. Myzel v. Fields, 386 F.2d 718, 742 (8th Cir. 1967), cert. denied, 390 U.S. 951 (1968).

239. See Comment, Private Remedies Available Under Rule 10b-5, 20 Sw. L.J. 620, 625-26 (1966). See also Painter, Inside Information: Growing Pains for the Development of Federal Corporation Law Under Rule 10b-5, 65 Colum. L. Rev. 1361, 1376 n.56 (1965).

240. See Comment, supra note 239 , at 626.

241. 2 A. BROMBERG $\$ 6.3$ (1130).

242. See, e.g., Chris-Craft Indus., Inc. v. Bangor Punta Corp., 480 F.2d 341 (2d Cir.), cert. denied, 414 U.S. 910 (1973).

Piper has come under the dominance of BPC, with many of its management positions being assumed by BPC officers. It has been operated that way for two or three years. Divestiture of the ill-gotten shares would not be appropriate under the circumstances of this case because it would be difficult to administer and would unnecessarily reopen the control battle. CCI understandably no longer desires to take control of a company that has been substantially changed. It seeks damages.

480 F.2d at 379.

243. I.R.C. $\S 111$, in conjunction with Treas. Reg. $\S 1.111-1(a)$ (1956). See Dobson v. Commissioner, 320 U.S. 489 (1943).

244. Lucas v. American Code Co., 280 U.S. 445, 449 (1930).

245. Chris-Craft Indus., Inc. v. Bangor Punta Corp., 480 F.2d 341, 357 (2d Cir.), cert. denied, 414 U.S. 910 (1973). 
ity to know his chances of recovery because of the complex nature of securities fraud litigation, even assuming he has overcome the obstacles to bringing suit under Rule 10b-5. A lenient application of the reasonable prospect of recovery test counter-balances the taxpayer's disadvantage. By allowing the theft loss deduction, the taxpayer receives current compensation for a current loss and the government recognizes that the taxpayer's assets have been reduced by the amount of the loss. The result is equitable in that the inclusion of a recovery as gross income balances the deduction from gross income allowed in the prior year such that there is no point in time when either the federal government or the taxpayer are unjustly enriched.

\section{Measuring the Loss}

For purposes of both theft loss and casualty loss deductions, the amount of the loss is the lesser of either the difference between the fair market value of the damaged property immediately before and immediately after the theft or the adjusted basis of the damaged property. ${ }^{246}$ However, the theft loss deduction is treated uniquely insofar as a regulation provides that the value of the property immediately after the theft is treated as zero. ${ }^{247}$ With respect to securities over which the shareholder can no longer exercise any dominion at the close of the taxable year, either because the SEC has suspended trading or because the security is no longer trading on an exchange, this regulation is practical. However, the stockholder might qualify for the theft loss deduction even when the stock retains some value. It must be remembered that the taxpayer is measuring a loss, not worthlessness. In such a case, the basis rules as applied to casualty losses could be applicable. ${ }^{248}$

The application of the tax law theory of measuring damages caused by a securities fraud presents problems which are beyond the scope of this Comment. First, few courts have reached the issue of how to measure damages under Rule $10 \mathrm{~b}-5 .{ }^{249}$ Second, assuming tax law limits damages to out-of-pocket loss, the computation is difficult insofar as one must discount the effect of normal market fluctuations in the price of the security. Nonetheless, one commentator has suggested a formula which would determine the actual value of the stock in ques-

246. Treas. Reg. \& 1.165-7(b)(z)-(ii) (1960).

247. Treas. Reg. \& 1.165-8(c) (1960).

248. See Treas. Reg. § 1.165-7(b); Treas. Reg. § 1.165-8(c). See also United States v. Rexach, 482 F.2d 10, 30 (1st Cir.), cert. denied, 414 U S. 540 (1973).

249. Mullaney, Theories of Measuring in Security Cases and the Effects of Damages on Liability, 46 FordHAM L. Rev. 277, 277 (1977). 
tion, absent the effect of fraud. ${ }^{250}$ The premise upon which such a formula is based is that "the efficiency of the market makes the price at which a security is actively traded an accurate indication of the true value of the security."251 The lost value which is attributable to the fraud is determined by conducting an investigation of the historical performance of an actively traded security which reveals the true value of the stock as compared to the value of the stock affected by the fraud. ${ }^{252}$ The difference is the amount of the theft loss deduction. Consequently, it is the securities markets which facilitate the measurement of the loss by providing reliable information as to the effect of the fraud on the security.

\section{CONCLUSION}

A theft loss deduction for noncorporate taxpayers who own securities which have declined in value as a proximate result of a securities fraud is a feasible solution to the dilemma which currently faces the small investor. The allowance for loss in this situation may be justified on intrinsic as well as extrinsic policy considerations.

The definition of theft, for purposes of federal income taxation, in cludes acts made unlawful by section 10(b) of the 1934 Securities Exchange Act and by Rule 10b-5. Private actions for damages, SEC proceedings and SEC referrals to the Department of Justice for criminal prosecution are all identifiable events as to which the taxpayer can be held to have discovered his loss. Furthermore, if the taxpayer can show either that he has no bona fide claims for recoupment or that, as to his bona fide claims for recoupment, there is no substantial possibility of recovery, then he has no reasonable prospect of recovery. Finally, the securities markets provide reliable information regarding the prices of securities from which the value of the stolen property can be ascertained.

Although this Comment was limited to a discussion of section 10(b) of the 1934 Securities Exchange Act, and Rule 10b-5, the analysis may also be applied to other anti-fraud provisions as to which shareholders have a direct right of action for damages. Moreover, such analysis is not limited to the securities laws but is potentially applicable to other federal anti-fraud statutes. In the context of a securities fraud, a theft loss deduction could provide small investors with some relief for

250. Note, The Measure of Damages in Rule 10b-5 Cases Involving Actively Traded Securities, 26 STAN. L. REv. 371, 385-86 (1974).

251. Id. 396.

252. Id. $397 \&$ app. 
the injury sustained-relief which neither the tax law nor the securities law has previously provided. 